\title{
On the Link between the Volatility and Skewness of Growth*
}

\author{
Geert Bekaert ${ }^{\dagger}$ \\ Columbia University
}

\author{
Alexander Popov \\ ECB
}

\begin{abstract}
In a sample of 110 countries over the period 1960-2009, we document a positive relation between the volatility and skewness of growth in the cross-section. This novel stylized fact is related to two distinct mechanisms: sudden growth spurts in emerging markets, and sharp financial crises-driven recessions in developed economies. The former phenomenon is driven by industrialization, macroeconomic stabilization, and the exploitation of natural resources. The latter is consistent with recent theories of financial frictions. The cross-sectional pattern contrasts with a negative relation between volatility and skewness in panel data with country fixed effects in the top quartile of countries in terms of beginning-of-period GDP per capita.

JEL classification: E32; G10; O10.

Keywords: Volatility; Skewness; Development; Financial frictions; Growth spurts; Business cycles.
\end{abstract}

${ }^{*}$ We thank George-Marios Angeletos, Robert Barro, Markus Brunnermeier, Francis Diebold, Oded Galor, Gita Gopinath, Francois Gourio, Bartozs Mackowiak, Kalin Nikolov, Harald Uhlig, Martin Uribe, Hans-Joachim Voth, Mark Watson, and Philippe Weil, as well as participants at various seminars and conferences, for useful discussions. The views expressed do not necessarily reflect those of the European Central Bank or the Eurosystem. The opinions expressed herein are those of the authors and do not necessarily reflect those of the ECB or the Eurosystem. Declarations of interest: none.

${ }^{\dagger}$ Graduate School of Business, Columbia University, 3022 Broadway, 411 Uris Hall, New York, NY 10027, and NBER, email: gb241@columbia.edu

${ }^{\ddagger}$ Corresponding author. European Central Bank, Financial Research Division, Sonnemannstrasse 20, D-60314 Frankfurt, email: Alexander.Popov@ecb.int 


\title{
On the Link between the Volatility and Skewness of Growth
}

\begin{abstract}
In a sample of 110 countries over the period 1960-2009, we document a positive relation between the volatility and skewness of growth in the cross-section. This novel stylized fact is related to two distinct mechanisms: sudden growth spurts in emerging markets, and sharp financial crises-driven recessions in developed economies. The former phenomenon is driven by industrialization, macroeconomic stabilization, and the exploitation of natural resources. The latter is consistent with recent theories of financial frictions. The cross-sectional pattern contrasts with a negative relation between volatility and skewness in panel data with country fixed effects in the top quartile of countries in terms of beginning-of-period GDP per capita.
\end{abstract}

JEL classification: E32; G10; O10.

Keywords: Volatility; Skewness; Development; Financial frictions; Growth spurts; Business cycles. 


\section{Introduction}

This paper documents a novel stylized fact: in a large cross-section of countries, the volatility and the skewness of GDP growth are positively correlated over the long run. As a concrete example, countries in the highest decile in terms of volatility ${ }^{1}$ exhibit an average skewness over the 1960-2009 period of 1.51 , while the lowest volatility decile exhibits an average skewness of -0.71 . The relation between volatility and skewness is significant and robust across time and space. For example, it holds for the top and the bottom quartile of countries both in terms of 1960 per capita GDP and in terms of subsequent average growth rate, it holds both before and after the Great Moderation, and it holds for both annual and quarterly underlying growth data.

What economic models best explain the positive relation between the volatility and skewness of GDP growth in the cross-section? One potential explanation is that the relation is driven by business cycle dynamics whereby the primary source of fluctuations in GDP growth are transitory fluctuations around a stable trend. However, the most basic version of such a model in the business cycle literature appears inconsistent with the stylized fact because it predicts a negative temporal relationship between volatility and skewness. A large number of papers have empirically established that business cycles are negatively skewed, with recessions occurring suddenly and being sharp, whereas booms occur more slowly (see, e.g., Diebold and Rudebusch, 1990; Hamilton, 1989; and Acemoglu and Scott, 1994). Models explaining this type of behaviour include, for example, Acemoglu and Scott (1997), who relate the business cycle asymmetry to intertemporal increasing returns to investment, and Zeira (1994), Jovanovic (2006), and Van Nieuwerburgh and Veldkamp (2006), whose models rely on a learning process in which either bad signals are more extreme than good signals, or signals are less noisy during booms. Given the recent interest in differences between business cycles in emerging markets and developed countries (see e.g. Aguiar and Gopinath, 2007; Garcia-Cicco, Pancrazi, and Uribe, 2010), an interesting question is whether this stylized fact is universal or restricted to the developed countries for which it has hitherto been documented. We show that in panel data with country fixed effects, volatility and skewness are indeed temporally negatively correlated, but only for the richer (mostly industrialized OECD) countries. Importantly, we show that for the same subset of countries, the volatility and skewness of growth are still

\footnotetext{
${ }^{1}$ While in the empirical tests we employ the natural logarithm of the standard deviation of GDP growth, in the text we interchangeably refer to the "volatility" of GDP growth.
} 
positively correlated in the cross-section.

A temporal negative correlation between volatility and skewness can only be reconciled with a positive correlation in the cross-section if lower-volatility countries receive on average larger transitory negative shocks. However, business cycle models suggest that the mechanisms which generate business cycle asymmetry are hardwired in the business cycle itself and do not depend on the size of the volatility-generating shocks. This also applies to the new generation growth-business cycle model of Comin and Gertler (2006) which uses technological change to generate mediumfrequency oscillations between periods of robust growth and periods of relative stagnation. In short, models capturing the negatively-skewed business cycle of small open economies do not offer a mechanism for the positive cross-sectional relationship between volatility and skewness observed in a large cross-section of countries, and in particular for the large share of high-volatility, highpositive-skewness countries in the data.

Could this stylized fact be generated by models of growth and development? Such models do a good job at explaining how an economy can transition from a period of underdevelopment to a period of rapid growth. For example, Acemoglu and Zilibotti (1997) suggest that under-developed countries, likely prevalent in our sample, are stuck in an equilibrium with high output variability as indivisibilities in the production process limits the economy's ability to diversify idiosyncratic risk. Only when they experience "lucky draws" do they accumulate enough capital to invest in large indivisible high-growth projects, at which point the economy takes off and volatility declines due to diversification. Furthermore, Acemoglu, Johnson, Robinson, and Thaicharoen (2003) identify institutions as the key determinant of the mean and variability of the growth process, and suggest that better institutions come with higher growth, lower volatility, and less severe contractions. Such models seemingly predict a negative cross-sectional relationship between skewness and volatility whereby over the development path, the growth process becomes simultaneously more positively skewed and less volatile. However, we show that the positive cross-sectional relationship we observe holds for all development levels. Theories modelling the transition from a "Malthusian" equilibrium (low economic growth and high population growth) to a "Solowian" equilibrium (high economic growth and low population growth), such as Galor and Weil (2000), Hansen and Prescott (2002) and Voigtlander and Voth (2009), suggest that at each point in time, a number of countries could be operating under both regimes. However, such models are primarily concerned with the rate 
of growth at different stages of development and they do not offer explicit predictions for the relationship between volatility and skewness.

The stylized fact we uncover can also be viewed as puzzling from the point of view of traditional models of financial frictions. For example, Bernanke and Gertler (1989), Bernanke, Gertler, and Gilchrist (1996), and Kiyotaki and Moore (1997) present models where microeconomic credit constraints amplify (exogenous) technological shocks. In a world without financial intermediation, volatility is low and growth skewness is zero as no amplification of shocks takes place in the absence of leverage. Financial development initially increases volatility by alleviating the capacity constraints on investment induced by positive technological shocks. As the financial system develops further, the capacity constraint binds only for large negative shocks, and as a result, volatility is reduced and the growth process becomes more negatively skewed. ${ }^{2}$ Finally, at very high (infinite) levels of financial development the capacity constraint never binds, reducing volatility further and increasing the skewness of growth. These models of financial frictions are consistent with a temporally negative relationship between volatility and skewness. However, they seem hard to reconcile with a cross-sectional pattern whereby the lowest-volatility countries are the most negatively skewed and where a number of countries are characterized by very volatile, very positively skewed growth process.

This short overview suggests that the main stylized fact established in this article is hard to reconcile with extant models. We argue that the positive cross-sectional relationship between the long-run volatility and long-run skewness of growth is reconciled by two separate mechanisms which are at play at different stages of development. First, for developed countries with sophisticated financial sectors, a positive link between volatility and skewness makes economic sense from the perspective of models developed to explain the recent global financial crisis. Following the Great Moderation, characterized by steady growth and low output volatility, many countries experienced a deep financial crisis, leading to a sharp decline in output growth. The economics profession has responded by building new macroeconomic models of endogenous risk with financial frictions.

\footnotetext{
${ }^{2}$ Related to this literature, Ranciere, Tornell, and Westermann (2008) study a model where systemic risk taking in financially liberalized economies with limited contract enforcement, reduces the effective cost of capital and relaxes borrowing constraints. This allows greater investment and generates higher long-term growth, but it raises the probability of a sudden collapse in financial intermediation when a crash occurs. Popov (2014) provides empirical evidence that equity market liberalization worsens the negative skewness of output growth, both directly and through the channel of more frequent banking-crises-driven recessions.
} 
A prime example in this literature is the model by Brunnermeier and Sannikov (2014). ${ }^{3}$ Their model generates a "volatility paradox", whereby agents respond to a low volatility environment by over-leveraging and creating latent endogenous variability which may then lead to a financial crisis. Conceptually, this model is reminiscent of the work of Minsky (1986) who contends that during good times (characterized by high growth and low volatility) speculative euphoria leads to a borrowing bubble, which leads to a financial crisis and a contraction. We document direct empirical evidence of this mechanism for the most financially developed countries. In particular, we find that protracted periods of low volatility are often followed by a systemic financial crisis, which is consistent with the idea that higher risk taking during periods of low volatility begets large macroeconomic contractions in the future. In such an environment, there is a natural cross-sectional positive relationship between lagged volatility and skewness, which may in turn help explain the long-term positive correlation between skewness and volatility, even though, contemporaneously, business cycle variation renders the relationship between volatility and skewness negative.

Such evidence alone, however, would not suffice to explain a cross-sectional positive relationship for our sample of 110 countries most of which are not industrialized economies. The second mechanism we uncover is related to sudden growth spurts in a considerable number of developing countries. These growth spurts generate positive skewness and come hand in hand with high growth volatility. For these countries, the temporal relationship between volatility and skewness is consistent with the long-run relationship. A variety of theoretical models of industrialization and early development relate such growth spurts to a transition from an agriculture-based to a manufacturing-based economy as happened during the Industrial Revolution (Murphy, Shleifer, and Vishny, 1991; Acemoglu and Zilibotti, 1997). While in our data over the 1960-2009 period there are a number of cases of growth spurts due to industrialization, most of the large and abrupt expansions we observe are associated with more prosaic developments, like the discovery and subsequent exploitation of natural resources, or post-war economic recovery. This pattern is reminiscent of but still different from the work of Broadberry and coauthors (see Fouquet and Broadberry, 2015; Broadberry and Wallis, 2017) on long run economic growth in Europe, even pre-dating the Industrial Revolution, which challenges the typical "take-off" theories. He documents periods of

\footnotetext{
${ }^{3}$ Mendoza (2010), He and Krishnamurthy (2012), and Dewachter and Wouters (2014) also present models of endogenous risk in a macroeconomic context.
} 
economic growth that look like growth spurts, but also long periods of economic decline. He claims that long-run development is more associated with the occurrences of "shrinking" decreasing relative to the frequency of periods of "growing." However, our results suggest that in the modern era, developing countries have typically higher skewness than do developed countries. This basic fact, confirmed using multiple data sets, is inconsistent with recent results in Ordonez (2013), who claims that emerging markets show more negative growth skewness than do developed countries.

To summarize, the novel stylized fact we present appears to be explained by two separate mechanisms in two different sets of countries. Countries at early stages of development, while occasionally hit by crises and sudden stops, experience periods of very rapid economic growth, generating high long-run volatility and simultaneously positive long-run skewness. Changes to growth trends are fundamental in this story. This mechanism is lacking in more developed economies, giving them the well-known business cycle pattern of a slow boom and a steep bust. Crucially, the latter pattern is exacerbated by the occasional severe financial crisis-driven contraction which follows periods of relatively low volatility, generating a positive correlation between long-run volatility and long-run skewness.

The paper proceeds as follows. In Section 2 we study the cross-sectional relationship between volatility and skewness, whereas Section 3 focuses on panel data. In Section 4, we dig deeper into development and financial frictions models that may help explain our results. In Section 5, we present a simple statistical data generating process, consistent with our empirical results. Section 6 provides concluding remarks.

\section{The Cross-Sectional Relationship Between Volatility and Skew- ness}

We first study the cross-sectional relationship between the long-term volatility and long-term skewness of output growth, as follows:

$$
\text { Skewness }_{i}=\beta_{1}+\beta_{2} \log \left(\text { Volatility }_{i}\right)+\varepsilon_{i}
$$

Here Skewness $_{i}$ is calculated as the Fisher-Pearson coefficient of skewness, and Volatility $i$ is 
calculated as the square root of the variance, i.e., the standard deviation, of GDP growth rates over the period 1960-2009, for each country $i$. To compute the two higher moments of growth, we use data on annual GDP growth from the Penn World Table (PWT) 7.0 for 110 countries that have data on GDP going back at least to 1960. PWT 7.0 reports growth rates calculated as the percentage change in GDP per capita between two periods. Later, we also report results where growth rates are calculated as first differences of log levels.

Volatility over the full sample ranges between $1.9 \%$ for Norway and $24.2 \%$ for Equatorial Guinea. The cross-sectional distribution of volatility is very right-skewed, which is not surprising. In fact, the skewness of volatility estimates is well documented in the statistics literature and it is wellknown that log-volatility shows a more normal distribution (see Andersen, Bollerslev, Diebold and Labys, 2003). To avoid that outliers drive the results, we use the log of volatility throughout our empirical analysis. The main results of the paper are only strengthened when we use the level of volatility. Figure 1 plots skewness versus log-volatility for the 110-country sample and a strong positive relationship is readily apparent.

Table 1, column (1) reports the point estimate of $\beta_{2}$ from a bivariate regression of long-term skewness on the logarithm of the long-term standard deviation of GDP growth. The estimate of the coefficient in this bivariate regression is 1.022 and it is significant at the $1 \%$ statistical level. The R-squared of the regression implies that the variation in log volatility explains a quarter of the variation in skewness in the cross-section. ${ }^{4}$ The magnitude of the coefficient implies that a 1-standard-deviation increase in volatility is associated with an increase in skewness representing half the standard deviation of skewness in the sample.

The strength of the statistical association between volatility and skewness remains unchanged in column (2) when we control for initial GDP per capita and for average GDP growth over the 1960-2009 period, as well as for standard determinants of growth, such as initial life expectancy and secondary school enrolment, average government share in GDP, population growth, and financial market depth, and a dummy for whether the country is an OECD member. At the same time, the magnitude of the association between volatility and skewness decreases by about $25 \%$. We also continue recording a positive significant association between skewness and volatility when we

\footnotetext{
${ }^{4}$ In comparison, in Ramey and Ramey (1995), the R-squared in the regression of growth on volatility in a crosssection of 92 countries is 0.06 .
} 
exclude countries that experienced at least one year of hyperinflation during the sample period (i.e., a $600 \%$ increase in the CPI), to account for the possibility that real GDP growth is mismeasured for those (column (3)). ${ }^{5}$

We next wish to establish whether this result is driven by a particular set of countries, or by a particular time period. Columns (4) and (5) examine whether the relationship is a "rich or poor country story." Interestingly, we find that the relationship holds strongly and in a statistically significant manner in both the lowest and the highest quartile of countries in terms of initial GDP per capita. Nevertheless, the OLS estimate is almost twice larger for the poorest quartile of countries relative to the richest quartile of countries, and the R-squared of the regression is 0.42 relative to 0.17. We conclude that the positive association between volatility and skewness is not exclusive to but nonetheless stronger for developing countries.

We next split the sample along the growth dimension. We run the main regression on the countries in the bottom quartile (column (6)) and in the top quartile (column (7)) of the distribution of average growth over the 1960-2009 period. We thus juxtapose the 28 slowest growing countries (with an average growth rate of $0.4 \%$ over the 50 -year period) with the 28 fastest growing countries (with an average growth rate of $4.2 \%$ ). Strikingly, in both cases the coefficient of the OLS regression has almost the exact same magnitude. The combined evidence in columns (2)-(5) thus suggests that our main result is not fully explained by the fact that growth rates are positively skewed in poor countries, generating a "high growth rate-high volatility" pattern. Higher volatility is associated with higher skewness at all stages of development and at all levels of growth. The fact that the cross-sectional correlation between volatility and skewness is present both across income groups and within income groups is the most striking fact in the paper.

In columns (8) and (9), we split the sample period in two and re-estimate the cross-sectional relationship between the skewness and volatility of GDP growth over 1960-1984 and 1985-2009, respectively. The cut-off year corresponds to the beginning of the Great Moderation (Stock and Watson, 2002), although the second period includes the 2008-09 global financial crisis. The positive association between volatility and skewness is observed over the two periods, but it is economically stronger in the post-1984 period. This is likely driven by developed countries experiencing particu-

\footnotetext{
${ }^{5}$ There are 8 such countries in the dataset: Argentina, Bolivia, Brazil, Chile, Democratic Republic of Congo, Indonesia, Nicaragua, and Peru.
} 
larly low volatility during the Great Moderation combined with negative skewness induced by the global financial crisis of 2008-09.

Our results are reminiscent of but different from Ramey and Ramey (1995) who argue that there is a negative trade-off between output growth and volatility. Interestingly, given the usual utility functions economic agents are endowed with, their stylized fact strongly suggests high volatility is invariably welfare reducing. Our results, in contrast, suggest that, holding average growth constant, there may be a true choice between high volatility-high skewness outcomes and low volatility-low skewness outcomes.

In Table 2, we re-calculate both long-run skewness and long-run volatility using growth rates calculated as the first difference in the log levels of per capita GDP from one year to the next. This approach makes growth volatility and especially growth skewness less sensitive to outliers compared to using growth rates based on percentage changes in per capita GDP, as reported by PWT 7.0. We then replicate all tests reported in Table 1. We note that in all regressions, the association between skewness and log volatility continues to be positive. Moreover, it is significant at the $1 \%$ statistical level in the simplest, bivariate specification (column (1)). In column (2), where we control for initial GDP per capita, for average growth, and for a range of standard determinants of growth, the correlation between the volatility and skewness of growth remains positive, albeit marginally insignificant at the $10 \%$ statistical level. We continue finding a positive significant association between skewness and volatility when we exclude countries that experienced at least one year of hyperinflation during the sample period (column (3)). Columns (4) and (5) confirm that, as before, the volatility and skewness of growth are positively correlated both in the poorest and in the richest countries. We also find that the positive correlation is statistically significant and economically meaningful for the fastest-growing countries (column (7)) and after the Great Moderation (column (9)), but it weakens in low-growth countries (column (6)) and in the sample before the Great Moderation (column (8)). Overall, the magnitude of the association between skewness and $\log$ volatility declines relative to the estimates reported in Table 1, confirming a potentially important role that growth outliers play in that association.

In Table 3, we subject our main stylized fact to a number of robustness checks related to the empirical proxies and to the data sources we employ. First, while using the natural logarithm of volatility mitigates the effects of outliers, the bulk of the literature on the volatility-growth link 
has used the level of GDP growth volatility as right-hand side variable instead (e.g., Ramey and Ramey, 1995; Posch and Walde, 2011). In column (1) we show that the positive association between growth volatility and skewness is preserved in a regression of long-term skewness on the level of long-term volatility. In column (2), we drop nine countries with a long-term standard deviation of GDP growth of more than 10 percent, showing that this positive association is not driven by a few countries with very volatile average growth rates.

Next, we examine the robustness of our results to the use of annual data. Our results may be systematically biased in favour of finding a positive correlation between volatility and skewness if the busts are sharper in annual data and concentrated in low-volatility countries. We download quarterly data on 33 OECD countries from the STAN Dataset for Industrial Analysis, and re-run our main specification. Column (3) indicates that the relationship we have uncovered is not driven by the use of less granular data and confirms its presence for a sample of only developed countries.

Next, we account for the fact that different updates of the Penn World Table can contain different real GDP growth series for the same country, despite being derived from similar underlying data and using almost identical methodologies. ${ }^{6}$ In some cases, there can be large differences. For example, according to the 7.0 update that we use throughout the paper, Guinea-Bissau recorded a GDP growth rate of $86 \%$ in 2005 , but according to the 7.1 update the country grew by $2 \%$ in 2005 . While such differences do not appear to be systematic, we repeat the main exercise with data from PWT 7.1. Column (4) indicates that our main result is robust to this alternative version of PWT. The same is true in column (5) where we calculate volatility and skewness of GDP growth using PWT 7.0, but we use only $50 \%$ of the countries, i.e. the ones for which the measure of skewness deviates the least from one version of the Penn Tables to the other.

Finally, the positive association between the volatility and skewness of GDP growth continues to be statistically and economically significant when we use entirely different data sources on GDP growth, such as the World Development Indicators (column (6)) and the International Financial Statistics of the IMF (column (7)).

\footnotetext{
${ }^{6}$ Katayama and Ponomareva (2010) and Johnson, Larson, Papageorgiou, and Subramanian (2013) document how differences in the GDP growth data across different versions of PWT matter for the cross-country growth literature.
} 


\section{Volatility and Skewness: Fixed Effects Panel Estimates}

We now turn to exploiting the panel nature of our cross-country dataset in order to study whether our data are consistent with the prior based on asymmetric business cycles, and how this prior can be reconciled with the strong, positive correlation between volatility and skewness of growth in the cross-section. To that end, we calculate Skewness and Volatility over reasonably long nonoverlapping periods. This allows us to control for observable time-varying country-specific effects in a model that includes both time and country fixed effects. Specifically, we introduce the following econometric framework:

$$
\text { Skewness }_{i t}=\beta_{1}+\beta_{2} \log \left(\text { Volatility }_{i t}\right)+\beta_{3} X_{i t}+\beta_{4} \mu_{i}+\beta_{5} \varphi_{t}+\varepsilon_{i t}
$$

where for each variable we compute its value over non-overlapping 10-year periods for each country $i$, yielding a panel of 550 observations. $X_{i t}$ is a set of time-varying country-specific control variables to be specified below; $\mu_{i}$ is a matrix of country dummies; and $\varphi_{t}$ is a matrix of year dummies. ${ }^{7}$

In Table 4, we start with the simplest possible panel regression in which the log standard deviation of growth is the only regressor and there are country fixed effects (column (1)). The relationship is insignificant both in this specification and when we also add time fixed effects (column (2)). The same is the case in column (3) where we use a Newey-West adjustment of the standard errors for country-specific autocorrelation (with 4 lags), to address the fact that GDP growth skewness could be serially correlated within countries. The association between volatility and skewness continues being insignificant when we do not adjust the standard errors for autocorrelation, and instead control for 1-period lagged skewness (column (4)), as well as when we exclude countries that experienced at least one year of hyperinflation during the sample period (column (5)). Finally, this non-result is confirmed in column (6), where we estimate our model on a smaller sub-sample of 33 countries with quarterly data.

In columns (7) and (8), analogous to the cross-sectional regression, we split the sample based on initial GDP per capita. We find an insignificant positive effect for the low GDP per capita countries but a strong negative effect in the sample of richer countries, which is significant at the

\footnotetext{
${ }^{7}$ The results are robust, and often stronger, when 5-year periods are used (available upon request).
} 
$5 \%$ statistical level. This finding raises the question at what particular level of development the negative skewness-volatility relationship becomes apparent. Column (9) reports the results of a regression where we include the natural logarithm of beginning-of-period GDP per capita, by itself and interacted with volatility. The coefficient on volatility itself is now significantly positive but the interaction effect is statistically significantly negative. We find that the coefficient on volatility turns negative at a per capita GDP level of $\$ 2110.82$ (in 2005 dollars), which is at the 41 st percentile of the GDP per capita distribution. Rich countries, controlling for volatility, have significantly lower growth skewness than poor countries.

How can the negative temporal correlation between volatility and skewness in richer countries, and the lack thereof in less developed ones, be reconciled with the positive long-term correlation that we uncovered in the cross-section and that holds both within and across income groups? We examine a number of potential channels in Table 5, using a range of empirical proxies, and discuss them in turn. Appendix Table 1 describes the variables and data sources, and Appendix Table 2 provides summary statistics.

\subsection{Recessions and Crises}

The first possibility is simply the asymmetric business cycle variation discussed before when growth slowdowns or negative growth periods coincide with high volatility. Aguiar and Gopinath (2007) argue that in emerging markets trend growth dominates cyclical growth which could explain the lack of a strong negative relationship for less developed countries. However, Garcia-Cicco, Pancrazi, and Uribe (2010), focusing on Argentina and Mexico, have disputed the conclusions in Aguiar and Gopinath (2007), showing that an RBC model driven by permanent and transitory productivity shocks fails to capture business cycle dynamics. Instead, a model with international financial frictions is called for. An even simpler explanation is that crises cause both volatility to increase and skewness to decrease simultaneously. However, it would be somewhat surprising that developed countries experience more, as well as more severe, crises than do emerging markets. To examine these two hypotheses, we must measure "crises" and "recessions." To define a recession, we set a dummy variable equal to 1 if the country experiences negative annual growth at any point during each 10-year period, and include it in the regression alongside its interaction with the log of the standard deviation of growth over each 10-year cycle (column (1)). The coefficient on the recession 
dummy is negative, while the coefficient on volatility and the coefficient on the interaction term are both positive, however, none of the effects is significant. We conclude that the negative association between volatility and skewness in richer countries does not appear to be driven by business cycle mechanisms.

A banking crisis simultaneously increases real volatility and causes output to fall, generating negative skewness. We use data from Laeven and Valencia (2010) to define a dummy equal to 1 if the economy is experiencing a systemic banking crisis at any point during each 10-year period, and include it in the regression together with its interaction with volatility (column (2)). The impact of both level variables and of the interaction variable are insignificant, suggesting that banking crises do not help explain the association between volatility and skewness.

\subsection{Financial development}

Next, we test for the effect of financial development on the trade-off between volatility and skewness. In the Kiyotaki and Moore (1997) model of financial frictions, borrowing capacity is a function of the firm's net worth and of the state of financial development. Because net worth fluctuates over the business cycle, real shocks are amplified when the collateral constraint binds, and whether it does depends on the state of financial intermediation. This model yields three distinct regimes. For very low levels of financial intermediation, the economy is in autarky as no borrowing takes place. Because of the absence of leverage, there is no amplification of shocks and as a result, the growth process is symmetric and characterized by low volatility. Away from autarky, financial development exerts a non-linear effect on volatility and on skewness. As financial markets develop initially, economic agents start accumulating leverage. In this case, the collateral constraint is frequently binding, leading to an amplification of net worth fluctuations which is manifested in higher output volatility. The more developed the financial system is, the less frequently the collateral constraint binds. Collateral amplification takes place only when the negative shocks are sufficiently large, and so the economy is characterized by low volatility and by negative skewness. This model has a hard time explaining our cross-sectional evidence where output growth in the highest-volatility countries is very positively skewed. However, as long as no country in the sample is perfectly financially developed (i.e., the capacity constraint still binds on the downside), the collateral amplification mechanism can explain the negative temporal correlation between volatility and skewness in the 
richest countries. We test this story by including the ratio of private credit to GDP from Beck, Demirgüç-Kunt, and Levine (2010), on its own and in interaction with volatility. Column (3) confirms that more financially developed economies have more negatively skewed business cycles, and this effect is significant at the 1 percent statistical level. The relationship between volatility and skewness is on average positive, but it turns negative beyond a Private credit / GDP threshold of 0.34 (the 66th percentile of the sample distribution), suggesting that the negative association between volatility and skewness documented in column (4) of Table 4 is partially driven by business cycle dynamics in relatively financially developed countries. ${ }^{8}$

Fortunately, our main results on the positive association between volatility and skewness in the cross section are not driven by the reliance on annual data, as demonstrated in Table 3, column (3) for a sub-sample of industrialized economies.

\subsection{Financial liberalization}

Next, we investigate the effect of financial openness. From a neoclassical perspective, there is a direct positive link between financial liberalization and output growth. By improving risk sharing post-liberalization, by reducing financing constraints as more foreign capital becomes available, and by bringing pressure from foreign investors to improve corporate governance, liberalization should decrease the cost of capital and increase investment, with a positive effect on growth (Bekaert and Harvey, 2000; Henry, 2000). While the positive effect of financial liberalization on growth is well-documented (e.g., Bekaert, Harvey, and Lundblad, 2005; Gupta and Yuan, 2009), evidence on its effect on growth volatility is decidedly mixed. For example, Stiglitz (2000) and Levchenko, Ranciere, and Thoenig (2009) argue that greater access to foreign capital increases volatility in the real economy, but Bekaert, Harvey and Lundblad (2006) find a negative but statistically insignificant effect on volatility. Finally, Ranciere, Thornell, and Westermann (2008) study the link between financial liberalization, growth, and crises, and find a strong positive link between long-term growth and financial fragility, while Popov (2014) documents that over the 1973-2009 period, countries

\footnotetext{
${ }^{8}$ Our evidence is inconsistent with the predictions laid out in a recent paper by Ordonez (2013). He uses a learning model with endogenous information flow to argue that financial frictions delay the economy's recovery after the bust phase. Using quarterly data on (at most) 52 countries, he finds that the skewness of output growth is more negative in less developed economies, a pattern opposite to what we observe in annual data on 110 countries. While his analysis excluded data from 2009 and we do not have access to quarterly IFS data, we cannot confirm many of the skewness numbers reported in the Ordonez paper using a number of different data sets (Worldbank, IFS, and PWT). Moreover, emerging markets have generally higher skewness than developed countries whatever the data set used.
} 
that became financially open experienced a large increase in the negative skewness of GDP growth relative to otherwise similar countries that remained closed to foreign portfolio investment.

The interplay between financial liberalization, growth volatility, and skewness is ultimately an empirical question. We include in the regression a dummy variable equal to 1 if the country is open to foreign portfolio investment at the beginning of each 10-period period, and also an interaction of that variable with 10 -year volatility. ${ }^{9}$ Column (4) confirms that financial openness does contribute significantly to the negative skewness of GDP growth. The coefficient on the interaction term is negative and significant, too, suggesting that the temporal correlation between volatility and skewness is positive in financially closed economies, but negative in financially liberalized ones.

\subsection{Trade}

Next, we investigate the effect of trade. Economies more open to trade may be more volatile because they are exposed to terms-of-trade risk (e.g., Rodrik, 1998; Epifani and Gancia, 2009), however, the impact of trade openness on growth skewness is unclear. For example, while a crisis may affect the non-tradeables sector, the traded goods sector may benefit from currency depreciation and lower prices in the non-tradeables sector. In unreported results, we include in the regression a dummy variable equal to 1 if the country is open to trade at the beginning of each 10-period period, and also an interaction with 10-year volatility. Data on trade openness come from Wacziarg and Welch (2008). We find that trade openness does contribute significantly to the negative skewness of GDP growth. However, the coefficient on the interaction is not significant, suggesting that openness to trade is not the reason for the development-dependent temporal negative relationship between volatility and skewness. In column (5), we test for terms-of-trade risk by including the standard deviation of the first (log) difference of the terms of trade over each respective 5-year period as an independent variable. We find that higher terms-of-trade volatility is associated with more a positively skewed growth process. However, the coefficient on the interaction is positive, suggesting that terms-of-trade volatility may help explain the positive correlation between skewness and growth in the cross-section, but it does not explain the temporal negative relationship between volatility and skewness in richer countries.

\footnotetext{
${ }^{9}$ We use the financial liberalization taxonomy in Bekaert, Harvey, and Lundblad (2005).
} 


\subsection{Government}

We also explore the role of the government sector. Higher government spending can be associated with a smoother business-cycle because transitory fluctuations are reduced through automatic stabilisers or discretionary changes in fiscal policy (e.g., Gali, 1994; Fatas and Mihov, 2006). By making recessions milder, government spending may therefore increase the skewness of growth. Column (6) suggests that government spending increases the skewness of output growth (albeit insignificantly so), suggesting a more stable business cycle with less pronounced busts in countries with high government spending. The coefficient on volatility is significantly negative but the interaction coefficient with government spending is positive and significant, suggesting that for countries with low government spending, there is a negative trade-off between volatility and skewness. The interaction effect implies that the association between volatility and skewness becomes positive beyond a government spending / GDP threshold of 0.12 (the 72nd percentile of the distribution). Because government spending excludes social security, it turns out that the countries exceeding this threshold are actually mostly developing countries, not the developed countries with mechanisms in place to mitigate the amplitude of the business cycle. It is therefore also possible that government spending is simply a reverse indicator of development, just as private credit to GDP and trade openness may also indirectly rank countries on development status.

\subsection{Growth spurts}

We now examine the growth spurt mechanism. Various theories provide endogenous mechanisms for countries to take off and experience growth acceleration after a long period of underdevelopment characterized by low growth. Some of these theories treat population growth as fixed (Goodfriend and McDermott, 1995), others propose an explicit mechanism which considers how population growth and technological growth affect each other (Galor and Weil, 2000; Galor and Moav, 2002). In some models, the economy needs a "lucky draw" to start on an upward path (Acemoglu and Zilibotti, 1997), and in others, co-ordination is required to achieve industrialization because no individual sector can break even by industrializing alone (Murphy, Shleifer, and Vishny, 1989). However, what all these growth theories have in common is a technology-driven transition from a pre-Industrial Revolution equilibrium, characterized by low GDP growth, to a post-Industrial 
Revolution equilibrium, characterized by high GDP growth. These theories have direct implications for our tests: if such growth spurts are large enough (and thus create volatility), they could induce a large positive temporal correlation between volatility and skewness. If a sufficient number of countries undergo such episodes, this may account for the fact that the negative temporal correlation between volatility and skewness that is prevalent in richer countries is much weaker in the full sample.

To test this prediction, in column (7) we include a variable capturing whether a country is experiencing a growth spurt during a particular 10-year period. We define a growth spurt using a dummy variable equal to 1 if the average growth rate over the 10 -year period is more than two standard deviations higher than the sample average, with this average and standard deviation measured across all countries and time periods. To make sure that we exclude growth spurts which are due to an outlier in the data potentially reflecting a data error (like Guinea-Bissau's $86 \%$ growth in 2005 according to PWT 7.0), we also require that during this 10-year period, the country records during at least two years a growth rate which is at least twice higher than the sample average. The union of the criteria results in an average growth over a 10-year period of 0.077 . We also include the interaction of this variable with volatility. The evidence confirms the intuition: while volatility and skewness are on average negatively temporally correlated, the coefficient on the interaction term implies that they become positively correlated during periods in which the economy is experiencing a growth spurt. Growth spurts themselves, not surprisingly, contribute significantly to the positive skewness of growth.

\subsection{Horse race}

Finally, in column (8) we run a horse race where we include all variables, ${ }^{10}$ as well as their interactions with volatility, simultaneously in the regression. Tellingly, the three effects that remain significant are those of private credit / GDP, government spending, and growth spurts. This suggests that business cycle mechanisms in rich countries and growth spurts in developing countries go a long way in explaining the development-dependent temporal association between volatility and skewness. ${ }^{11}$

\footnotetext{
${ }^{10}$ We exclude the terms-of-trade variable which has too many missing values.

${ }^{11}$ In an unreported regression, we also include the logarithm of GDP per capita and its interaction with volatility in the horse race. The effect of financial development and of growth spurts still obtains, implying that the development
} 
What is the nature of the growth spurts in our dataset? In traditional models of early growth, take-off is due to the process of industrialization, i.e., the transition from an economy based on agriculture to one with a diversified fast-growing manufacturing base. These models are designed to capture the experience of what are now industrialized countries during the 18th and 19th century (Galor and Weil, 2000), but they also aim to capture post-WWII developments which are subsumed in our data period, such as the Big Push in Korea during the 1960s and 1970s (Murphy, Shleifer, and Vishny, 1989). Table 6 lists the growth spurt episodes in our data, alongside the reason for the rapid growth. From 16 such episodes, 7 can indeed be classified as Industrial Revolution-type growth spurts: Hong-Kong in 1960-1969, Japan in 1960-1969, Romania in 1960-1969 and in 19701979, Singapore in 1970-1979, Taiwan in 1970-1979, and China in 2000-2009. The majority of the remaining episodes (7) are related to the discovery and exploitation of natural resources (mostly oil) and/or a sudden increase in global demand for such resources or for agricultural products. Two are related to economic stabilisation and/or liberalization in the wake of political independence or a war.

In Table 7, we perform three robustness tests. In column (1), we exclude growth spurts which are preceded by a persistent growth decline, i.e., a 10-year period during which the country experienced negative average growth. Whereas the growth spurt narrative above seems inconsistent with this conjecture, this specification tests whether growth spurts are simply a rebound after a crisis, which may be more severe in emerging markets. However, the results are entirely robust. In column (2), we include "growth miracles" in the growth spurt definition. While the latter are periods of fast growth that may nevertheless be short-lived, the former are usually understood as sustained periods of economic growth and convergence in per-capita income. We define "growth miracles" as countryspecific episodes of at least two consecutive ten-year periods with annual growth higher than 0.05 (the 88th percentile of 10-year average growth rates in the full sample), and assign a value of 1 to such episodes. Using this criterion, we add Gabon, Korea, and Thailand to the sample of growth spurt countries. The resulting sample consists of 16 countries, and it now includes 5 countries which experienced a large-scale convergence during the sample period: Botswana, Equatorial Guinea, and Thailand, which moved from the bottom quartile to the third quartile of the per-capita GDP distribution, and Korea and Taiwan which moved from the second to the top quartile of the perchannels we test in Table 5 explain well the development-dependent relationship between volatility and skewness. 
capita GDP distribution. Finally, in column (3) we include 1-period-lagged skewness of GDP growth, to account for the fact that skewness may be a proxy for risk taking, which by itself can lead to higher growth, generating reverse causality in the regression. The pattern that we uncover in column (7) of Table 5 survives these alternative specifications and alternative definition of growth spurt episodes.

\section{The Volatility Paradox: Does Low Volatility Breed Negative Skewness?}

We are still left with a puzzle. In the cross-section, there is a strong positive association between the volatility and skewness of growth. In panel data, the relationship is overall negative, but becomes positive for less developed countries. We documented that asymmetric business cycles explain the negative coefficient for developed countries in the panel. We also showed that growth spurts in developing countries can explain a temporal positive correlation between volatility and skewness. How can such patterns lead to the strong positive cross-sectional relationship documented in Table 1 for all stages of development? Growth spurts explain the positive relationship in the bottom quartile of countries in terms of GDP per capita. However, the evidence we have presented does not reconcile the strong negative temporal association between volatility and skewness with the strong positive long-term association between the two in the top echelon of countries in terms of per capita GDP (Table 1, column (5)), especially after 1984 (the year of the commonly accepted start of the Great Moderation). If anything, rich countries with deeper recessions should have a higher long-term volatility than rich countries with less deep recessions, inducing a negative cross-sectional variation between long-run volatility and long-run skewness. At the same time, however, some rich countries have experienced large macroeconomic contractions because they had low volatility for too long, which led to over-leveraging and a sharp financial crisis. This is a temporal but not a contemporaneous relation between low volatility and negative skewness that can help explain the positive long-run association between the two in the cross-section. By populating the high and low

quadrant of the cross-sectional distribution of volatility correctly, the cross-sectional relationship becomes strongly positive. We explore this "story" now in more detail.

A narrative going back to Minsky (1986) suggests that good (high-growth, low-volatility) times 
give rise to speculative investor euphoria, and soon thereafter debts exceed what borrowers can pay off from their incoming revenues, which in turn leads to a financial crisis. As a result of the collapse of the speculative borrowing bubble, investors - and especially banks - reduce credit availability, even to companies that can afford to borrow, and the economy subsequently contracts. This narrative suggests that past volatility and future skewness can correlate positively. Building on similar models by Bernanke and Gertler (1989), Bernanke, Gertler, and Gilchrist (1996), and Kiyotaki and Moore (1997), Brunnermeier and Sannikov (2014) formalize this story through a mechanism in which agents react to an exogenous decline in macroeconomic risk by accumulating higher leverage. As a result, a low exogenous risk environment is conducive to a greater build-up of systemic risk. In this setting, instability is higher when aggregate risk is low, implying that a period of low volatility should be followed by a sharp crisis (a period of negative skewness), especially in economies whose financial markets are developed enough as to enable a build-up of leverage beyond the critical threshold. If reaching particular low levels of volatility was associated with an increased propensity for large, abrupt, and rare macroeconomic contractions in the future, this could explain a positive link between volatility and skewness at high levels of financial development. For this to contribute to the positive cross-sectional relationship, it must be the case that the volatility induced by the crisis itself does not push these countries into the upper part of the cross-sectional volatility distribution.

In Table 8, we test these implications of the Brunnermeier-Sannikov model. In particular, we regress the skewness of GDP growth onto the lagged standard deviation of GDP growth and on lagged private credit / GDP, plus the interaction between the two. In the full sample, not surprisingly, we do not find any statistically significant coefficient. This is hardly surprising given that the Brunnermeier-Sannikov model is only relevant for economies that have sufficiently developed financial sectors. In the second column, we focus on the top tertile of the sample in terms of average private credit / GDP over the 1960-2009 period. In this specification, the coefficient on lagged volatility is negative and significant at the $5 \%$ statistical level, and the coefficient on the interaction term is positive and significant at the $10 \%$ statistical level. The interpretation of these results is that at relatively low levels of financial development, low volatility in the previous period is still negatively associated with future skewness. However, at private credit / GDP levels of more than 0.89 , the relationship turns positive. While the threshold may seem somewhat high, there 
are 27 countries in the sample that experience private credit / GDP levels beyond that threshold during at least one 10-year period. In 12 of these, the combination of a period of low volatility and over-the-threshold levels of domestic credit was followed by a systemic banking crisis, as defined by Laeven and Valencia (2010). ${ }^{12}$ These regressions also include country and time fixed effects and the controls used in Table 5. These tests thus provide strong evidence that periods of low volatility may be causally linked to future periods of crises (negative skewness), especially for countries in later stages of financial development.

Figures 2 and 3 illustrate the two main mechanisms which are at work in the cross-section in the long run. The evolution of GDP growth in Equatorial Guinea (Figure 2) is marked by the discovery of large oil fields in 1996. As a result of their subsequent exploration, Equatorial Guinea experienced a rapid growth spurt; for example, its GDP tripled between 1996 and 1998. This development is mapped into the highest growth volatility over 1960-2009 in our sample, 0.242, as well as the third highest skewness, 2.676, although prior to 1996 the country's economy was characterized by a symmetric and relatively steady (low) growth process.

At the opposite end of the development cycle is the UK (Figure 3). Characterized by a lowvolatility growth all the way up to the recent crisis, its economy experienced a very deep contraction in 2009 following the banking crisis of 2007-08. The resulting skewness of -1.176 is one of the lowest in the cross-section, despite the fact that UK's growth volatility over 1960-2009 is the fourth lowest at 0.020 .

\section{$5 \quad$ A Statistical Growth Model}

The empirical findings in this article are not easily reconciled with economic theory, but they also raise statistical challenges. Most growth models assume Gaussian shocks, but we document a relationship between a second and a third moment, which may vary over time within a country and vary across countries, depending on their level of development. There is an empirical literature that attempts to test whether single equilibrium standard development and/or growth models are consistent with the data or whether the data suggests multiple equilibriums. In essence these

\footnotetext{
${ }^{12}$ These countries are: Austria (2008-), Denmark (2008-), France (1998), Japan (1997-1998 and 2008-) Malaysia (1997-1999), Netherlands (2008-), Portugal (2008-), Spain (2008-), Sweden (1991-1995 and 2008-), Switzerland (2008-), the United Kingdom (2008-), and the United States (2008-).
} 
models test for non-linearities of the type that we also document in the data. For example, Bloom, David, and Sevilla (2003) suggest that GDP per capita follows a two regime process, whereas Owen, Videras, and Davis (2009) find evidence in favour of two regimes estimating a standard growth regression. What we set out to do here is to show that a fairly simple statistical model is potentially consistent with our findings.

The basic framework borrows from the "BEGE" or Bad Environment Good Environment model proposed in Bekaert and Engstrom (2017). The key assumption is that there are two shocks to the growth process, a "good" non-Gaussian shock drawn from a positively skewed distribution, and a "bad" non-Gaussian shock drawn from a negatively skewed distribution. Which of the shocks dominates, and thus determines the conditional volatility and skewness of the growth process, can depend on fundamentals, such as the degree of economic and financial development.

Formally, the model for output growth is given by the following equation:

$$
y_{t+1}=\bar{g}+x_{t}+\sigma_{y p} \omega_{p, t+1}-\sigma_{y n} \omega_{n, t+1}
$$

where $y_{t+1}$ is the 1-period change in per capita output. $\bar{g}$ is the unconditional mean rate of output growth, and $x_{t}$ is the deviation of the conditional growth rate from $\bar{g}$. Because our findings concern higher-order moments, we abstract from the conditional mean for now and focus on the shocks. Both $\sigma_{y p}$ and $\sigma_{y n}$ are positive. The shocks $\omega_{p, t+1}$ and $\omega_{n, t+1}$ are zero-mean innovations that come from gamma distributions, as follows:

$$
\begin{aligned}
& \omega_{p, t+1}=\varphi_{t+1}-p_{t} \\
& \omega_{n, t+1}=\phi_{t+1}-n_{t}
\end{aligned}
$$

Here, $\varphi_{t+1}$ represents a "good environment" variable and $\phi_{t+1}$ represents a "bad environment" variable, where $\varphi_{t+1} \sim \Gamma\left(p_{t}, 1\right)$ and $\phi_{t+1} \sim \Gamma\left(n_{t}, 1\right)$. The first parameter is the shape parameter; the second is the scale parameter of the gamma distribution which is normalized to 1 , because the $\sigma$-parameters govern the scale of the processes. The shape parameter $p_{t}$ governs the width of the positive tail, and the shape parameter $n_{t}$ governs the width of the negative tail, of $y_{t+1}$. Because 
the mean of the gamma distribution is equal to its shape parameter when the size parameter is one, the terms $-p_{t}$ in Equation (4) and $-n_{t}$ in Equation (5) ensure that each shock has a conditional mean of 0 .

Bekaert and Engstrom (2017) show that in this framework, the second and the third unscaled conditional moments of $y_{t+1}$ can be rewritten as:

$$
\begin{gathered}
E_{t}\left[\left(y_{t+1}-\left(\bar{g}+x_{t}\right)\right)^{2}\right]=\sigma_{y p}^{2} p_{t}-\sigma_{y n}^{2} n_{t}=\operatorname{var}_{t} \\
E_{t}\left[\left(y_{t+1}-\left(\bar{g}+x_{t}\right)\right)^{3}\right]=2 \sigma_{y p}^{3} p_{t}-2 \sigma_{y n}^{3} n_{t}=\text { skew }_{t}
\end{gathered}
$$

Equation (6) demonstrates that both $p_{t}$ and $n_{t}$ contribute positively to the conditional variance of output. However, Equation (7) demonstrates that they differ in their implications for the conditional skewness of output. Skewness, defined as $\frac{s k e w_{t}}{\operatorname{var}_{t}^{\frac{3}{2}}}$, is positive when $\sigma_{y p}^{3} p_{t}$ is relatively large, and negative when $\sigma_{y n}^{3}$ is relatively large. While both the "good environment" and the "bad environment" shocks are on average zero, there is a higher probability of a good shock in a good environment, and vice versa. Importantly, the conditional covariance between skewness and volatility equals $2 \sigma_{y p}^{5} \operatorname{var}\left(p_{t}\right)-2 \sigma_{y n}^{5} \operatorname{var}\left(n_{t}\right)$. Depending on how the dynamics of $p_{t}$ and $n_{t}$ are modelled, this covariance can be positive or negative and change over time. In the original BekaertEngstrom model, for example, the shape parameters follow autoregressive processes, driven by the same shocks as the growth process.

For our purposes, we are mostly interested in the cross-section of output growth. Therefore, we assume that all countries follow the same process but that the parameters depend on fundamentals and change with economic and financial development. Specifically, we assume that the first shape parameter is a function of economic development, captured by per capita output, $Y_{t}$, and that the second shape parameter is a function of financial development, $F_{t}$, as follows:

$$
p_{t}=\left\{\begin{array}{l}
p^{L} \text { if } Y_{t}<\bar{Y} \\
p^{H} \text { if } Y_{t} \geq \bar{Y}
\end{array}\right.
$$

and 


$$
n_{t}=\left\{\begin{array}{l}
n^{L} \text { if } F_{t}<\bar{F} \\
n^{H} \text { if } F_{t} \geq \bar{F}
\end{array}\right.
$$

where $L$ and $H$ define low and high economic, respectively, financial development. This gives the potential for 4 different development regimes, with the main transition of interest that of going from early stages of development with low per capita GDP and an under-developed financial sector, to later stages of development where GDP per capita is much higher and the financial sector is more developed. In the first stage, the model must generate positive skewness to make growth spurts more likely. In the second stage, growth variability should decrease and the likelihood of growth spurts should diminish. As the financial intermediation sector develops further, the Minsky and Brunnermeier-Sannikhov mechanisms come into play and growth becomes negatively skewed as severe, banking crisis-driven recessions become possible.

The parameter configurations that can deliver such development cycle are not easily pinned down. While unscaled skewness is increasing (decreasing) in $p_{t}\left(n_{t}\right)$, because the variance is increasing in $p_{t}$ and $n_{t}$, the derivative of scaled skewness with respect to $p_{t}$ or $n_{t}$ cannot be signed. However, if the $\sigma-$ (scale) parameters and $p_{t}$ and $n_{t}$ are of similar magnitude, skewness is increasing in $p_{t}$ and decreasing in $n_{t}$. The same is true if the variance contribution of "bad" and "good" variance to the total variance are about equal and the sigma parameters are not too different. Thus, in such a world, low-development regimes are characterized by high $p$ (or low $n$ ) and high-development regimes by high $n$ (low $p$ ). However, this intuition is no longer valid if either $\sigma_{y p}$ (in the low-development regime) or $\sigma_{y n}$ (in the high-development regime) is relatively large. Importantly, the model is flexible enough to generate such regimes and regime transitions.

We calibrate a BEGE model as in Equations (3)-(9) to our growth data to illustrate how it can fit our key empirical facts. To further introduce flexibility, we assume that the $\sigma$ parameters also vary with the regime. That implies that there are a total of 8 parameters. In Table 9 , we report the results. To implement the model, we split the sample into 4 bins based on development cut-off values applied to the full cross-country panel distribution of per capita real GDP, as a measure of economic development, and private credit to GDP, as a measure of financial development. We set the threshold for development at the two-thirds point in the distribution. The first column in Table 9 lists standard deviations and skewness coefficients over the 4 bins with $95 \%$ percent confidence 
intervals. Note that the first letter indicates economic development (low or high) and the second letter indicates financial development (low or high). Development, be it economic or financial, invariably lowers the variability of GDP growth rates. More relevant for our story, is that financial development decreases skewness both in low and high economic development states. A GMM test confirms that the decrease is statistically significant at the $1 \%$ level in both cases.

Because we have 8 parameters and 8 moments, in principle we should be able to fit the moments exactly. Unfortunately, to obtain a perfect fit, the model selects parameters with very small $n^{L}$ values. When the shape parameters go to zero, the de-meaned gamma distribution becomes very skewed and at 0 it is degenerate. We therefore opt to conduct an extensive parameter grid search, looking for parameter configurations that fit the statistics laid out above very well, but where the $p$ - and $n$ - parameters are bounded away from zero. The first set we report minimizes the sum of squared residuals from the eight moment conditions (using the unscaled skewness rather than the scaled skewness) and imposes the conditions $p^{L}>0.25 ; p^{H}>0.2 ; n^{H}>0.15$. At these parameters, the skewness coefficients are all well within the $95 \%$ confidence interval, but standard deviations in financially developed economies are somewhat too high.

In the next column, we report a parameter configuration that satisfies the key fact that skewness decreases with financial development and yields statistics that are insignificantly different from the data for a minimum of 3 out of 4 standard deviations and skewness coefficients. Again the fit with the skewness coefficients is very good, and skewness decreases with higher financial development, reaching -1.84 , on average, when an economy is both economically and financially developed. As to standard deviations, economic and financial development lower the standard deviation, albeit by less than they do in the data.

Looking at the parameter estimates, the $p$-parameters are similar across regimes, but the $n$ parameter is much lower in the high financial development regime. It is this switch in parameters that causes growth to be more negatively skewed with high financial development. In a regime of low economic and financial development, $86.44 \%$ of the variance is driven by the good environment, positively skewed shock; in the regime of high economic and financial development, $67.25 \%$ of the variance is driven by the bad environment, negatively skewed shock. In the other model, the good environment, positively skewed shocks account for $66.07 \%$ of the total variance. Note that the $p$-variable is quite low in that regime, potentially generating large positive skewness. In the high 
development regime, the bad environment variable only accounts for $43.75 \%$ of the total variance, but it is very negatively skewed helping to generate severe recessions.

Of course, this model is extremely parsimonious and cannot fit all empirical facts. Apart from the link between skewness and volatility, useful empirical facts also include the cumulative output loss of banking crises, reported to be $10 \%$ in Abiad, Balakrishnan, Brooks, Leigh, and Tytell (2009), or the average annual growth rates of catch-up economies, which Szirmai (2012) reports to be between $6 \%$ and $12 \%$. This would also require us to model the mean of the growth process, which is outside the scope of the paper.

\section{Conclusion}

In a sample of 110 countries during the 1960-2009 period, the volatility and skewness of GDP growth are positively correlated in the cross-section. This fact is novel and somewhat puzzling, especially given the negative temporal correlation between volatility and skewness observed in panel analysis with country fixed effects in the top quartile of countries in terms of beginning-of-period GDP per capita. We argue that existing models have a hard time providing an explanation for this stylized fact. For example, in a number of business cycle theories, the skewness of GDP growth is hardwired in the business cycle due to learning asymmetries and so is orthogonal to the standard deviation of the distribution of real shocks (e.g., Van Nieuwerburgh and Veldkamp, 2006). Theories of early development and industrialization (e.g., Acemoglu and Zilibotti, 1997) do not fully explain the prevalence of low-volatility low-skewness countries in the sample, and financial accelerator-type theories (e.g., Bernanke and Gertler, 1989; Kiyotaki and Moore, 1997) have no mechanism for generating a high-volatility positive-skewness growth profile in developing economies.

We argue that there are two main, disjoint forces at play in the cross-section. First, a number of developing countries experience abrupt economic expansions, which can be short-lived ("growth spurts") or sustained ("growth miracles"). While some are related to industrialization, many are the outcome of the discovery and exploitation of natural resources, and others are due to macroeconomic stabilisation following political conflict. Second, a number of developed countries experience periods of low volatility, followed by systemic financial crises and large macroeconomic contractions, a mechanism consistent with the narrative in Minsky (1986) and Brunnermeier and Sannikov 
(2014). While such countries experience the highest volatility during the contractions (explaining the temporally negative association between volatility and skewness), the relative magnitude of the contraction can be inversely related to the preceding long-term volatility. These two phenomena jointly explain the co-existence of high-volatility positive-skewness and of low-volatility negative-skewness countries in the cross-section. They are illustrated in Figure 4 where the growth spurt countries occupy the upper right quadrant of the data points, and the financially developed countries that experience high levels of aggregate private leverage occupy the lower left quadrant.

While we invoke two separate mechanisms to explain the positive correlation between volatility and skewness in the cross-section, our data contain examples of a single country subject to both mechanisms in the long run. Figure 5 presents the evolution of GDP growth in Japan between 1950 and 2009. The first period, between 1951 and 1973, is characterized by high albeit volatile growth, following rapid industrialization in the wake of WWII. The second period, between 1975 and 2009, is a period of slower economic growth and lower volatility, especially after 1991. This same period contains two systemic financial crises, the one following the dual stock market and real estate boom of the 1980s and the global financial crisis of 2008-09. Thus, Japan illustrates how a country can in a fairly short time period go from an emerging industrializing economy characterized by high, volatile, positively-skewed growth process to a low-growth low-volatility industrialized country with a highly developed financial sector ${ }^{13}$ that can accumulate excessive debt and cause a systemic crisis.

Our evidence has implications for the calibration of various business cycle models, especially in emerging markets. Kydland and Zarazaga (2002) and Aguiar and Gopinath (2007), among others, have suggested that a Real Business Cycle (RBC) model driven by permanent shocks to productivity can replicate satisfactorily business cycles in developing countries, in particular the behaviour of output and consumption volatility. Our evidence suggests that in modelling business cycles in emerging markets, it is important to provide mechanisms matching higher order moments, too. In particular, a calibration of RBC models in emerging markets should be simultaneously mindful of the positive relation between volatility and skewness over the long-run and of the lack of a negative short-run relation between the second and third moment of output growth, which is nonetheless prevalent in developed economies.

\footnotetext{
${ }^{13}$ After Iceland in 2006 and Cyprus in 2009, Japan in 1998 had the highest ratio of private credit to GDP in our sample, at 2.31 .
} 
Recent unified growth models provide an endogenous mechanism for the transition from pre- to post-industrialization based on the accumulation of knowledge (Galor and Weil, 2000; Hansen and Prescott, 2002). However, we are not aware of growth models that also capture the "late" stage of development characterized by low volatility and occasional severe recessions led by financial crises. In Section V, we motivate our empirical findings with a data generating process where per capita growth is subject to two separate non-Gaussian shocks, one positively skewed which dominates at early stages of economic development, and one negatively skewed which dominates at later stages of financial development. However, the evidence presented in this paper calls for thorough model-building endeavors in this direction. ${ }^{14}$

\footnotetext{
${ }^{14}$ For an early argument advocating a tighter link between theory and evidence in a similar vein, see Klenow and Rodriguez-Clare (1997).
} 


\section{References}

[1] Abiad, A., Balakrishnan, R., Brooks, P., Leigh, D., and I. Tytell, 2009. What's the damage? Medium-term output dynamics after banking crises. IMF Working Paper 09/245.

[2] Acemoglu, D., and A. Scott, 1994. Asymmetries in the cyclical behavior of UK labor markets. Economic Journal 104, 1302-1323.

[3] Acemoglu, D., and A. Scott, 1997. Asymmetric business cycles: Theory and time-series evidence. Journal of Monetary Economics 40, 501-533.

[4] Acemoglu, D., and F. Zilibotti, 1997. Was Prometheus unbound by chance? Risk, diversification, and growth. Journal of Political Economy 105, 709-751.

[5] Acemoglu, D., Johnson, S., Robinson, J., and Y. Thaicharoen, 2003. Institutional causes, macroeconomic symptoms: Volatility, crises, and growth. Journal of Monetary Economics 50, $49-123$.

[6] Aguiar, M., and G. Gopinath, 2007. Emerging market business cycles: The cycle is the trend. Journal of Political Economy 115, 69-102.

[7] Andersen, T., Bollerslev, T., Diebold, F.X., and P. Labys, 2003. Modelling and forecasting realized volatility. Econometrica $71,576-625$.

[8] Beck, T., Demirgüç-Kunt, A., and R. Levine, 2010. A new database on financial development and structure. World Bank Economic Review 14, 597-605.

[9] Bekaert, G, and E. Engstrom, 2017. Asset return dynamics under habits and Bad Environment Good Environment fundamentals. Journal of Political Economy 125, 713-760.

[10] Bekaert, G., and C. Harvey, 2000. Foreign speculators and emerging equity markets. Journal of Finance 55, 565-613.

[11] Bekaert, G., Harvey, C., and C. Lundblad, 2005. Does financial liberalization spur growth? Journal of Financial Economics 77, 3-55. 
[12] Bekaert, G., Harvey, C., and C. Lundblad, 2006. Growth volatility and financial market liberalization. Journal of International Money and Finance 25, 370-403.

[13] Bernanke, B., and M. Gertler, 1989. Agency costs, net worth, and business fluctuations. American Economic Review 79, 14-31.

[14] Bernanke, B., Gertler, M., and S. Gilchrist, 1996. The financial accelerator and the flight to quality. Review of Economics and Statistics 78, 1-15.

[15] Bloom, D., David, C., and J. Sevilla, 2003. Geography and poverty traps. Journal of Economic Growth 8, 355-378.

[16] Broadberry, S., and J. Wallis, 2017. Growing, shrinking, and long run economic performance: Historical perspectives on economic development. NBER Working Paper 23343.

[17] Brunnermeier, M., and Y. Sannikov, 2014. A macroeconomic model with a financial sector. American Economic Review 104, 379-421.

[18] Comin, D., and M. Gertler, 2006. Medium-term business cycles. American Economic Review $96,523-550$.

[19] Dewachter, H., and R. Wouters, 2014. Endogenous risk in a DSGE model with capitalconstrained financial intermediaries. Journal of Economic Dynamics and Control 43, 241-268.

[20] Diebold, F., and G. Rudebusch, 1990. A non-parametric investigation of duration dependence in the American business cycle. Journal of Political Economy 98, 596-616.

[21] Epifani, P., and G. Gancia, 2009. Openness, government size, and terms of trade. Review of Economic Studies 76, 629-668.

[22] Fatas, A., and I. Mihov, 2006. The macroeconomic effects of fiscal rules in the U.S. states. Journal of Public Economics 90, 101-117.

[23] Fouquet, R., and S. Broadberry, 2015. Seven centuries of European economic growth and decline. Journal of Economic Perspectives 29, 227-244.

[24] Galor, O., and D. Weil, 2000. Population, technology, and growth: From Malthusian stagnation to the demographic transition and beyond. American Economic Review 90, 806-828. 
[25] Galor, O., and O. Moav, 2002. Natural selection and the origin of economic growth. Quarterly Journal of Economics 117, 1133-1191.

[26] Garcia-Cicco, J., Pancrazi, R., and M. Uribe, 2010. Real business cycles in emerging countries? American Economic Review 100, 2510-2531.

[27] Gali, J., 1994. Government size and macroeconomic stability. European Economic Review 38, 117-132.

[28] Goodfriend, M., and J. McDermott, 1995. Early development. American Economic Review 85, 116-133.

[29] Gupta, N., and K. Yuan, 2009. On the growth effect of stock market liberalizations. Review of Financial Studies 22, 4715-4752.

[30] Hamilton, J., 1989. A new approach to the economic analysis of non-stationary time series and the business cycle. Econometrica 57, 357-384.

[31] Hansen, G., and E. Prescott, 2002. Malthus to Solow. American Economic Review 92, 12051217.

[32] He, Z., and A. Krishnamurty, 2012. A macroeconomic framework for quantifying systemic risk. Mimeo.

[33] Henry, P. B., 2000. Stock market liberalization, economic reform, and emerging market equity prices. Journal of Finance 55, 529-564.

[34] Johnson, S., Larson, W., Papageorgiou, C., and A. Subramanian, 2013. Is newer better? Penn World Table revisions and their impact on growth estimates. Journal of Monetary Economics $60,255-274$.

[35] Jovanovic, B., 2006. Asymmetric cycles. Review of Economic Studies 73, 145-162.

[36] Katayama, H., and N. Ponomareva, 2010. Does the version of the Penn World Tables matter? An analysis of the relationship between growth and volatility. Canadian Journal of Economics 43, 152-179. 
[37] Kiyotaki, N., and J. Moore, 1997. Credit cycles. Journal of Political Economy 105, 211-248.

[38] Klenow, P., and A. Rodriguez-Clare, 1997. Economic growth: A review essay. Journal of Monetary Economics 40, 597-617.

[39] Kydland, F., and C. Zarazaga, 2002. Argentina's lost decade. Review of Economic Dynamics $5,152-165$.

[40] Laeven, L., and F. Valencia, 2010. Resolution of banking crises: The good, the bad, and the ugly. IMF working paper 10/146.

[41] Levchenko, A., Ranciere, R., and M. Thoenig, 2009. Growth and risk at the industry level: The real effects of financial liberalization. Journal of Development Economics 89, 210-222.

[42] Mendoza, E., 2010. Sudden stops, financial crises, and leverage. American Economic Review 100, 1941-1966.

[43] Minsky, H, 1986. Stabilizing an Unstable Economy. New Haven: Yale University Press.

[44] Murphy, K., Shleifer, A., and R. Vishny, 1989. Industrialization and the Big Push. Journal of Political Economy 97, 1003-1026.

[45] Ordonez, G., 2013. The asymmetric effects of financial frictions. Journal of Political Economy $121,844-895$.

[46] Owen, A., Videras, J., and L. Davis, 2009. Do all countries follow the same growth process? Journal of Economic Growth 14, 265-286.

[47] Popov, A., 2014. Credit constraints, equity market liberalization, and growth rate asymmetry. Journal of Development Economics 107, 202-214.

[48] Posch, O., and K. Walde, 2011. On the link between volatility and growth. Journal of Economic Growth 16, 285-308.

[49] Ramey, G., and V. Ramey, 1995. Cross-country evidence on the link between volatility and growth. American Economic Review 85, 1138-1151. 
[50] Ranciere, R., Tornell, A., and F. Westermann, 2008. Systemic crises and growth. Quarterly Journal of Economics 123, 359-406.

[51] Reinhart, C., and K. Rogoff, 2011. From financial crash to debt crisis. American Economic Review 101, 1676-1706.

[52] Rodrik, D., 1998. Why do more open economies have bigger governments? Journal of Political Economy 106, 997-1032.

[53] Sachs, J., and A. Warner, 1995. Economic reform and the process of global integration. Brookings Papers on Economic Activity 1, 1-118.

[54] Stiglitz, J., 2000. Capital market liberalization, economic growth, and instability. World Development $28,1075-1086$.

[55] Stock, J., and M. Watson, 2002. Has the business cycle changed and why? NBER Chapters, in: NBER Macroeconomics Annual 17, 159-230.

[56] Szirmai, A., 2012. Industrialisation as an engine of growth in developing countries. Structural Change and Economic Dynamics 23, 406-420.

[57] Van Nieuwerburgh, S., and L. Veldkamp, 2006. Learning asymmetries in real business cycles. Journal of Monetary Economics 53, 753-772.

[58] Voigtlander, H., and H. J. Voth, 2009. Malthusian dynamism and the rise of Europe: Make war, not love. American Economic Review 99, 248-254.

[59] Wacziarg, R., and K. Welch, 2008. Trade liberalization and growth: New evidence. World Bank Economic Review 22, 187-231.

[60] Zeira, J., 1994. Informational cycles. Review of Economic Studies 61, 31-44. 
Figure 1 - Skewness of Output Growth against Log Standard Deviation of Output Growth, 110 Countries, 1960-2009

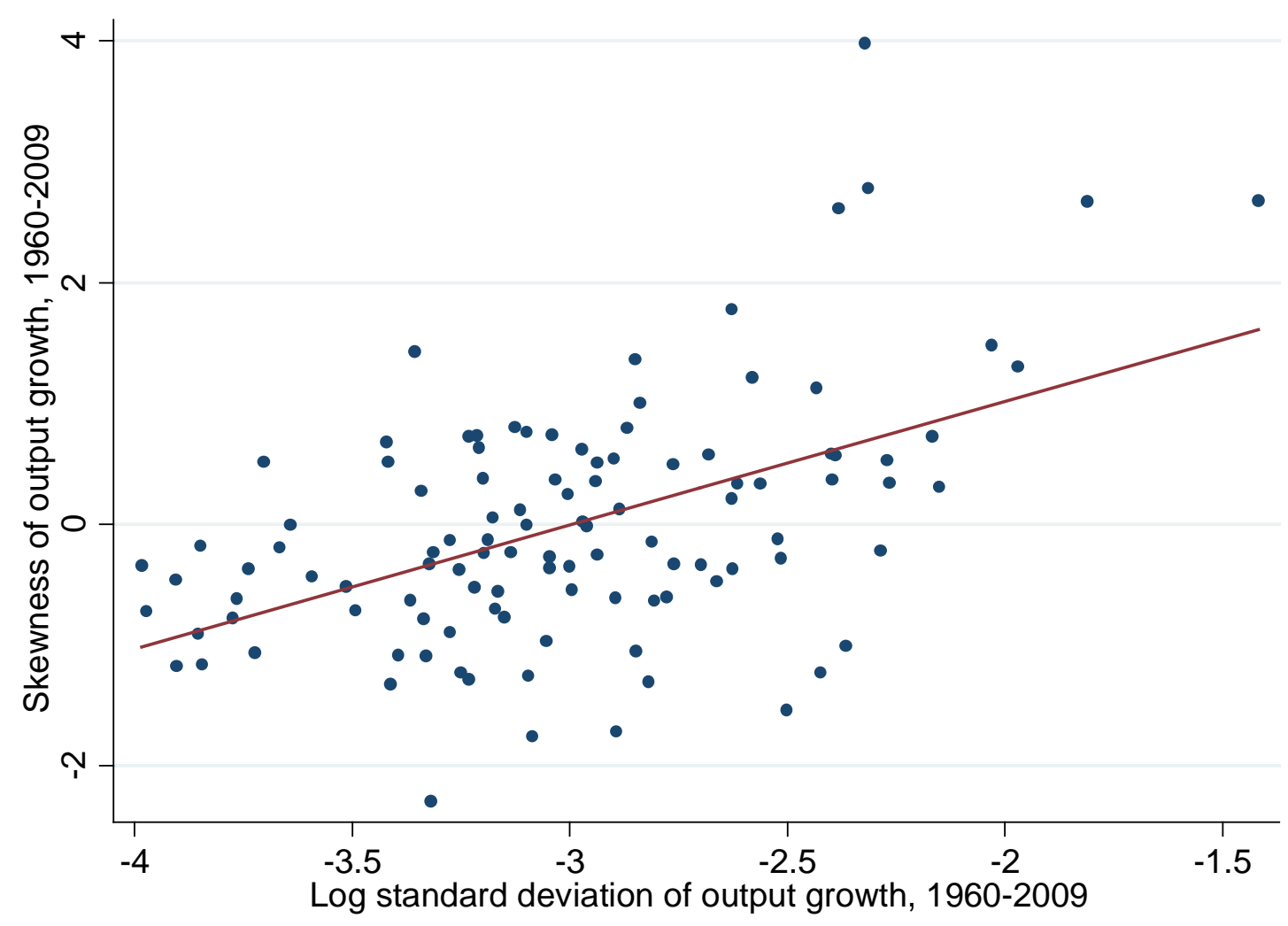


Figure 2 - Output Growth, Equatorial Guinea

Growth $=0.098 ;$ St. dev. $=0.242 ;$ Skewness $=2.676$

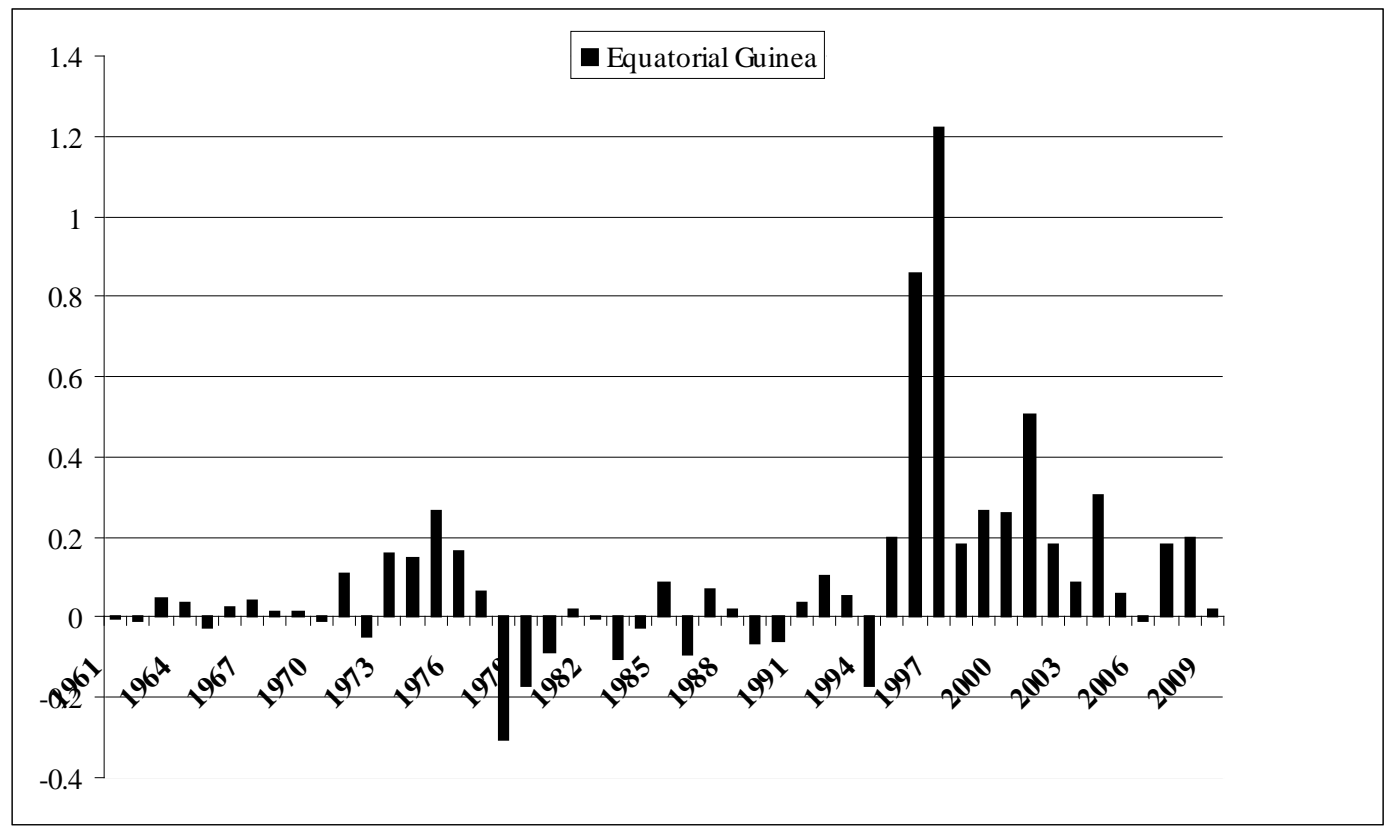

Kernel distribution of real GDP growth, 1960-2009

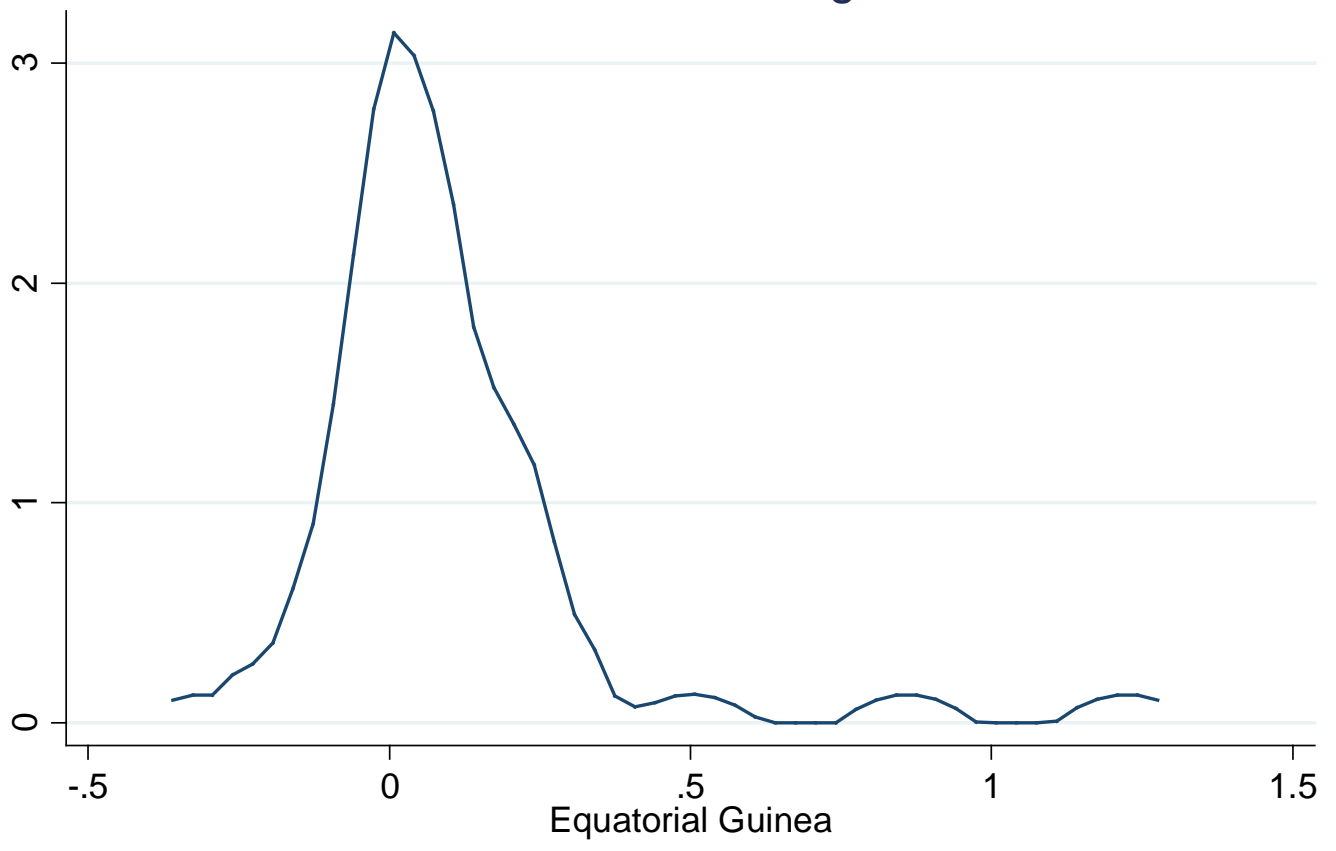

kernel $=$ epanechnikov, bandwidth $=0.0529$ 
Figure 3 - Output Growth, United Kingdom

Growth $=0.008 ;$ St. dev. $=0.020 ;$ Skewness $=-1.176$
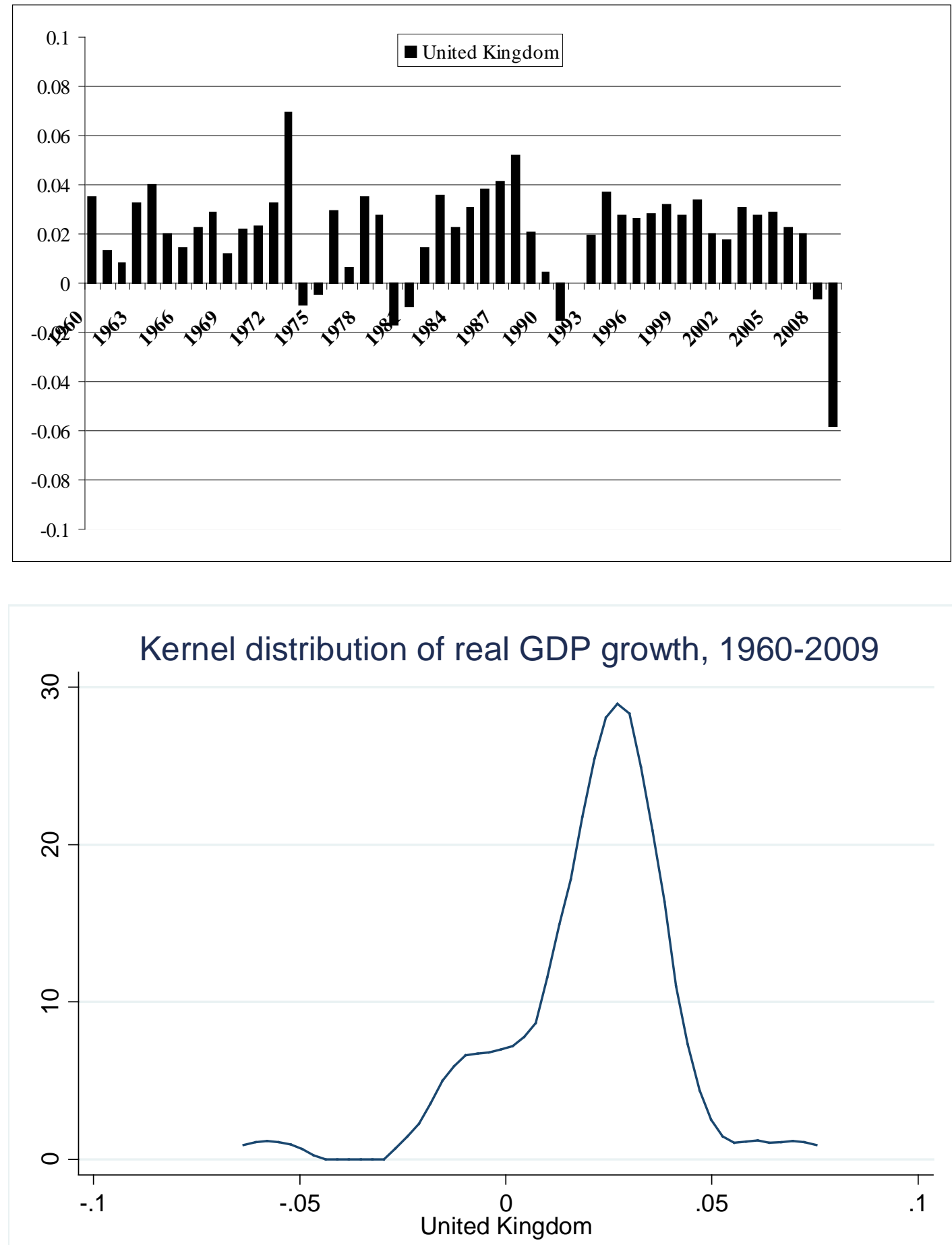

kernel $=$ epanechnikov, bandwidth $=0.0057$ 
Figure 4 - Low-Volatility \& Bank-Crisis Countries and Growth-Spurt Countries

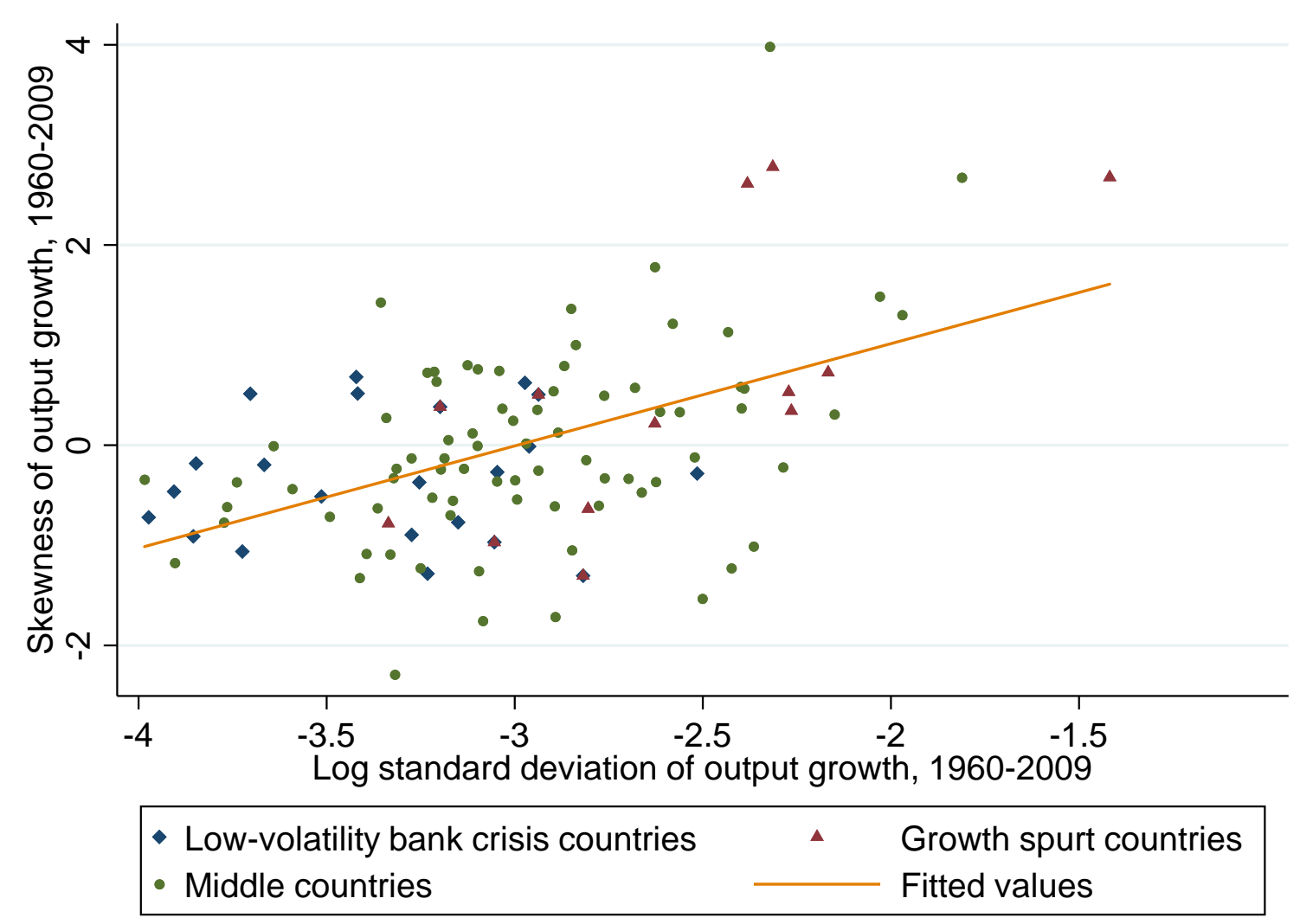


Figure 5 - Output Growth, Japan

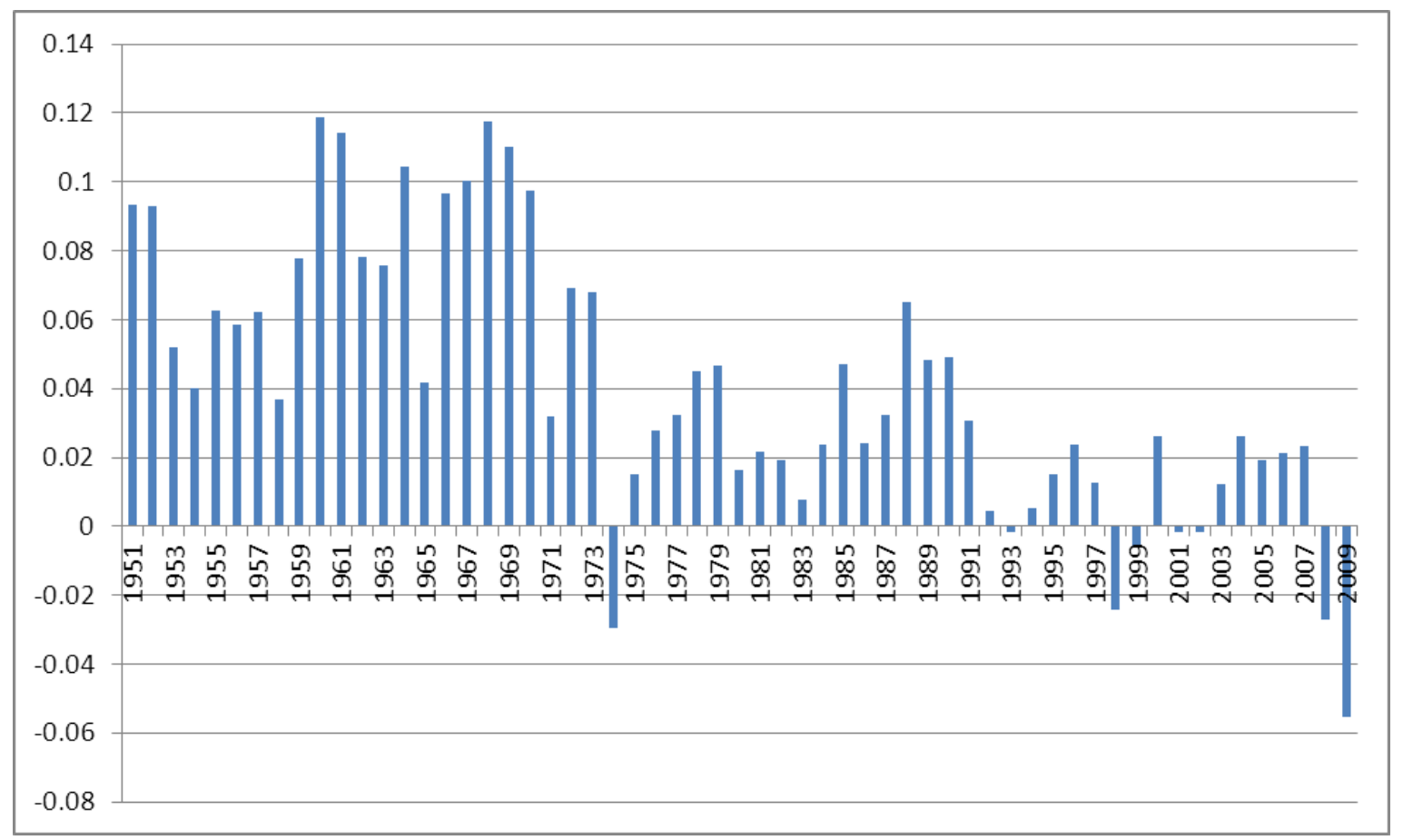


Table 1 - The Skewness of GDP Growth and the Natural Logarithm of the Standard Deviation of GDP Growth: Cross-Sectional Results

\begin{tabular}{|c|c|c|c|c|c|c|c|c|c|}
\hline & $\begin{array}{c}\text { Full sample } \\
\text { (1) }\end{array}$ & $\begin{array}{l}\text { Full sample, } \\
\text { growth } \\
\text { controls } \\
(2) \\
\end{array}$ & $\begin{array}{c}\text { Excluding } \\
\text { high-inflation } \\
\text { countries } \\
\text { (3) }\end{array}$ & $\begin{array}{c}1^{\text {st }} \text { quartile, } \\
\text { initial GDP } \\
\text { per capita } \\
(4) \\
\end{array}$ & $\begin{array}{l}4^{\text {th }} \text { quartile, } \\
\text { initial GDP } \\
\text { per capita } \\
(5) \\
\end{array}$ & $\begin{array}{l}1^{\text {st }} \text { quartile, } \\
\text { growth } \\
(6)\end{array}$ & $\begin{array}{l}4^{\text {th }} \text { quartile, } \\
\text { growth } \\
\text { (7) }\end{array}$ & $\begin{array}{c}1960-1984 \\
(8)\end{array}$ & $\begin{array}{c}1985-2009 \\
(9)\end{array}$ \\
\hline Log (St. dev. GDP growth) & $\begin{array}{l}1.022 * * * \\
(0.167)\end{array}$ & $\begin{array}{l}0.771 * * * \\
(0.224)\end{array}$ & $\begin{array}{l}1.034 * * * \\
(0.162)\end{array}$ & $\begin{array}{l}1.398 * * * \\
(0.307)\end{array}$ & $\begin{array}{l}0.684^{* *} \\
(0.266)\end{array}$ & $\begin{array}{l}1.075 * * * \\
(0.323)\end{array}$ & $\begin{array}{l}1.104 * * * \\
(0.163)\end{array}$ & $\begin{array}{l}0.366 * * \\
(0.142)\end{array}$ & $\begin{array}{l}1.104^{* * *} \\
(0.163)\end{array}$ \\
\hline Initial GDP per capital & & $\begin{array}{l}0.051 \\
(0.160)\end{array}$ & & & & & & & \\
\hline Average GDP growth & & $\begin{array}{l}0.081 \\
(0.068)\end{array}$ & & & & & & & \\
\hline Log (Initial life expectancy) & & $\begin{array}{l}1.097 \\
(0.860)\end{array}$ & & & & & & & \\
\hline Government share & & $\begin{array}{l}2.797^{* *} \\
(1.268)\end{array}$ & & & & & & & \\
\hline Initial sec. school enrolment & & $\begin{array}{l}-1.604 * * \\
(0.679)\end{array}$ & & & & & & & \\
\hline Population growth & & $\begin{array}{l}0.205 \\
(0.157)\end{array}$ & & & & & & & \\
\hline Credit / GDP & & $\begin{array}{l}-0.120 \\
(0.368)\end{array}$ & & & & & & & \\
\hline OECD dummy & & $\begin{array}{l}0.746 * * \\
(0.313)\end{array}$ & & & & & & & \\
\hline Observations & 110 & 107 & 102 & 28 & 28 & 28 & 28 & 110 & 110 \\
\hline R-squared & 0.25 & 0.31 & 0.28 & 0.42 & 0.17 & 0.20 & 0.30 & 0.06 & 0.30 \\
\hline
\end{tabular}

Notes: The skewness and the standard deviation of GDP growth are calculated for all countries in the sample for the 1960-2009 period (column (1)-(7)), for the 1960-1984 period (column (8)), and for the 1985-2009 period (column (9)). In column (2), we controls for GDP per capita in 1960, average GDP growth between 1960 and 2009, life expectancy in 1960, average share of government spending in total GDP, secondary school enrolment in 1960, average population growth, average ratio of private credit to GDP, and an indicator variable equal to one if the country is a member of the OECD. In column (3), countries that experienced at least one year of $600 \%$ inflation or more during the sample period are excluded. Data on GDP growth, calculated as the percentage change in percapita GDP from one year to the next, from the 7.0 update of the Penn World Table are used. Initial GDP per capita quartiles are determined based on GDP per capita in 1960. Growth quartiles are determined based on average GDP growth over the 1960-2009 period. Standard errors are provided in parentheses. *** indicates a p-value less than 0.01, ** indicates a p-value less than 0.05 . 
Table 2 - The Skewness of GDP Growth and the Natural Logarithm of the Standard Deviation of GDP Growth: Log growth

\begin{tabular}{|c|c|c|c|c|c|c|c|c|c|}
\hline & $\begin{array}{c}\text { Full sample } \\
\text { (1) }\end{array}$ & $\begin{array}{l}\text { Full sample, } \\
\text { growth } \\
\text { controls } \\
(2)\end{array}$ & $\begin{array}{c}\text { Excluding } \\
\text { high-inflation } \\
\text { countries } \\
\text { (3) }\end{array}$ & $\begin{array}{c}1^{\text {st }} \text { quartile, } \\
\text { initial GDP } \\
\text { per capita } \\
(4) \\
\end{array}$ & $\begin{array}{l}4^{\text {th }} \text { quartile, } \\
\text { initial GDP } \\
\text { per capita } \\
(5)\end{array}$ & $\begin{array}{l}1^{\text {st }} \text { quartile, } \\
\text { growth } \\
(6)\end{array}$ & $\begin{array}{l}4^{\text {th }} \text { quartile, } \\
\text { growth } \\
\text { (7) }\end{array}$ & $\begin{array}{c}1960-1984 \\
(8)\end{array}$ & $\begin{array}{c}1985-2009 \\
(9)\end{array}$ \\
\hline Log (St. dev. GDP growth) & $\begin{array}{l}0.533^{* * *} \\
(0.170)\end{array}$ & $\begin{array}{l}0.297^{\#} \\
(0.209)\end{array}$ & $\begin{array}{l}0.596^{* * * *} \\
(0.164)\end{array}$ & $\begin{array}{l}0.886^{* * * *} \\
(0.316)\end{array}$ & $\begin{array}{l}0.671 * * \\
(0.237)\end{array}$ & $\begin{array}{l}0.117 \\
(0.530)\end{array}$ & $\begin{array}{l}0.576 * \\
(0.356)\end{array}$ & $\begin{array}{l}0.092 \\
(0.144)\end{array}$ & $\begin{array}{l}0.722 * * * \\
(0.171)\end{array}$ \\
\hline Initial GDP per capital & & $\begin{array}{l}-0.040 \\
(0.165)\end{array}$ & & & & & & & \\
\hline Average GDP growth & & $\begin{array}{l}0.101 \\
(0.072)\end{array}$ & & & & & & & \\
\hline Log (Initial life expectancy) & & $\begin{array}{l}1.302 * \\
(0.878)\end{array}$ & & & & & & & \\
\hline Government share & & $\begin{array}{l}1.982 * \\
(1.286)\end{array}$ & & & & & & & \\
\hline Initial sec. school enrolment & & $\begin{array}{l}-1.463^{* *} \\
(0.689)\end{array}$ & & & & & & & \\
\hline Population growth & & $\begin{array}{l}0.219 \\
(0.160)\end{array}$ & & & & & & & \\
\hline Credit / GDP & & $\begin{array}{l}-0.166 \\
(0.376)\end{array}$ & & & & & & & \\
\hline OECD dummy & & $\begin{array}{l}0.479 * \\
(0.320)\end{array}$ & & & & & & & \\
\hline Observations & 110 & 107 & 102 & 28 & 28 & 28 & 28 & 110 & 110 \\
\hline R-squared & 0.08 & 0.13 & 0.11 & 0.20 & 0.21 & 0.01 & 0.06 & 0.01 & 0.13 \\
\hline \multicolumn{10}{|c|}{$\begin{array}{l}\text { Notes: The skewness and the standard deviation of GDP growth are calculated for all countries in the sample for the 1960-2009 period (column (1)-(7)), for the } \\
1960-1984 \text { period (column (8)), and for the 1985-2009 period (column (9)). In column (2), we controls for GDP per capita in 1960, average GDP growth } \\
\text { between } 1960 \text { and 2009, life expectancy in 1960, average share of government spending in total GDP, secondary school enrolment in 1960, average population } \\
\text { growth, average ratio of private credit to GDP, and an indicator variable equal to one if the country is a member of the OECD. In column (3), countries that } \\
\text { experienced at least one year of } 600 \% \text { inflation or more during the sample period are excluded. Data on GDP growth, calculated as the difference in the natural } \\
\text { logarithm of per-capita GDP from one year to the next, from the } 7.0 \text { update of the Penn World Table are used. Initial GDP per capita quartiles are determined } \\
\text { based on GDP per capita in 1960. Growth quartiles are determined based on average GDP growth over the 1960-2009 period. Standard errors are provided in } \\
\text { parentheses. *** indicates a p-value less than 0.01, ** indicates a p-value less than 0.05, * indicates a p-value less than 0.10, and }{ }^{\#} \text { indicates a p-value less than } \\
0.15 \text {. }\end{array}$} \\
\hline
\end{tabular}


Table 3 - The Skewness of GDP Growth and the Natural Logarithm of the Standard Deviation of GDP Growth: Cross-Sectional Results Using Alternative Empirical Proxies and Data Sources

\begin{tabular}{|c|c|c|c|c|c|c|c|}
\hline & $\begin{array}{c}\text { Volatility } \\
\text { (1) }\end{array}$ & $\begin{array}{l}\text { Volatility, no } \\
\text { outliers } \\
(2) \\
\end{array}$ & $\begin{array}{l}\text { STAN quarterly } \\
\text { data } \\
(3) \\
\end{array}$ & $\begin{array}{c}\text { PWT } 7.1 \text { data } \\
(4)\end{array}$ & $\begin{array}{c}\text { PWT } 7.0 \text { and } 7.1 \\
\text { data } \\
(5)\end{array}$ & $\begin{array}{l}\text { WDI data } \\
\text { (6) }\end{array}$ & $\begin{array}{c}\text { IFS data } \\
(7)\end{array}$ \\
\hline Log (St. dev. GDP growth) & $\begin{array}{l}16.801 * * * \\
(2.473)\end{array}$ & $\begin{array}{l}19.633^{* * *} \\
(4.260)\end{array}$ & $\begin{array}{l}0.864 * * \\
(0.428)\end{array}$ & $\begin{array}{l}0.803^{* * *} \\
(0.178)\end{array}$ & $\begin{array}{l}0.797 * * * \\
(0.221)\end{array}$ & $\begin{array}{l}0.688 * * * \\
(0.221)\end{array}$ & $\begin{array}{l}0.522 * * * \\
(0.148)\end{array}$ \\
\hline Observations & 110 & 101 & 33 & 110 & 55 & 89 & 142 \\
\hline R-squared & 0.30 & 0.17 & 0.12 & 0.16 & 0.18 & 0.09 & 0.08 \\
\hline
\end{tabular}

Notes: The skewness and the standard deviation of GDP growth are calculated for all countries in the sample for the 1960-2009 period. In column (1), the right-hand side variable is the standard deviation of GDP growth over 1960-2009, in levels. In column (2), the right-hand side variable is the standard deviation of GDP growth over 1960-2009, in levels, and we exclude countries with long-term volatility of GDP growth of more than ten percent. In column (3), quarterly data on GDP growth from the STAN Dataset on Industrial Analysis are used to calculate long-run volatility and skewness. In column (4), data on GDP growth are from the 7.1 update of the Penn World Table. In column (5), data on GDP growth are from the 7.0 update of the Penn World Tables, and the top 50\% of the countries in terms of the difference in skewness between the 7.0 and the 7.1 update are dropped. In column (6), data on GDP growth are from the World Bank's World Development Indicators. In column (7), data on GDP growth are from the IMF's International Financial Statistics. Standard errors are provided in parentheses. $* * *$ indicates a p-value less than $0.01, * *$ indicates a p-value less than 0.05 . 
Table 4 - The Skewness of GDP Growth and the Natural Logarithm of the Standard Deviation of GDP Growth: Panel Regression Results

\begin{tabular}{|c|c|c|c|c|c|c|c|c|c|}
\hline & $\begin{array}{c}\text { Full sample } \\
(1)\end{array}$ & $\begin{array}{c}\text { Full sample } \\
(2)\end{array}$ & $\begin{array}{c}\text { Full sample, } \\
\text { AC } \\
(3)\end{array}$ & $\begin{array}{c}\text { Full sample } \\
(4)\end{array}$ & $\begin{array}{c}\text { Excluding } \\
\text { high-inflation } \\
\text { countries } \\
(5) \\
\end{array}$ & $\begin{array}{c}\text { Quarterly } \\
\text { data } \\
(6)\end{array}$ & $\begin{array}{c}1^{\text {st }} \text { quartile } \\
\text { (7) }\end{array}$ & $\begin{array}{c}4^{\text {th }} \text { quartile } \\
\text { (8) }\end{array}$ & $\begin{array}{c}\text { Full sample } \\
(9)\end{array}$ \\
\hline Log (St. dev. 10-year GDP growth) & $\begin{array}{l}0.041 \\
(0.083)\end{array}$ & $\begin{array}{l}-0.004 \\
(0.085)\end{array}$ & $\begin{array}{l}-0.004 \\
(0.107)\end{array}$ & $\begin{array}{l}0.055 \\
(0.099)\end{array}$ & $\begin{array}{l}0.061 \\
(0.088)\end{array}$ & $\begin{array}{l}-0.215 \\
(0.346)\end{array}$ & $\begin{array}{l}0.264 \\
(0.193)\end{array}$ & $\begin{array}{l}-0.396 * * \\
(0.207)\end{array}$ & $\begin{array}{l}1.170 * * \\
(0.494)\end{array}$ \\
\hline $\begin{array}{l}\text { 1-period lagged 10-year GDP } \\
\text { skewness }\end{array}$ & & & & $\begin{array}{l}-0.208 * * * \\
(0.058)\end{array}$ & & & & & \\
\hline Log (GDP per capita) & & & & & & & & & $\begin{array}{l}-0.817 * * * \\
(0.215)\end{array}$ \\
\hline Log (10-year output volatility) $\times$ & & & & & & & & & $-0.153 * * *$ \\
\hline Log (GDP per capita) & & & & & & & & & $(0.063)$ \\
\hline Country dummies & Yes & Yes & Yes & Yes & Yes & Yes & Yes & Yes & Yes \\
\hline Period dummies & No & Yes & Yes & Yes & Yes & Yes & Yes & Yes & Yes \\
\hline Observations & 550 & 550 & 550 & 440 & 510 & 92 & 140 & 140 & 550 \\
\hline Countries & 110 & 110 & 110 & 110 & 102 & 33 & 28 & 28 & 110 \\
\hline R-squared & 0.22 & 0.24 & 0.24 & 0.34 & 0.24 & 0.63 & 0.11 & 0.35 & 0.27 \\
\hline
\end{tabular}

Notes: The skewness and the standard deviation of GDP growth are calculated for all countries in the sample for ten-year non-overlapping periods over 1960-2009. Annual data on GDP growth from the 7.0 update of the Penn World Table are used (columns (1)-(5) and columns (7)-(9)). The regressions include country (column (1)) and country and period (columns (2)-(9)) fixed effects. GDP per capita refers to the country's per capita GDP in the beginning of each 5 year period. In column (3), a Newey-West adjustment of the standard errors for panel-specific autocorrelation with 4 lags is used. In column (5), countries that experienced at least one year of $600 \%$ inflation or more during the sample period are excluded. In column (6), quarterly data on GDP growth from the STAN Dataset on Industrial Analysis are used. In columns (7) and (8), quartiles are determined based on GDP per capita in 1960. Standard errors are provided in parentheses. *** indicates a p-value less than 0.01 , * indicates a p-value less than 0.10 
Table 5 - The Skewness of GDP Growth and the Natural Logarithm of the Standard Deviation of GDP Growth:

Country Heterogeneity

\begin{tabular}{|c|c|c|c|c|c|c|c|c|}
\hline & $\begin{array}{c}\text { Recession } \\
(1) \\
\end{array}$ & $\begin{array}{c}\text { Banking } \\
\text { crisis } \\
(2) \\
\end{array}$ & $\begin{array}{c}\text { Private } \\
\text { credit / GDP } \\
\text { (3) }\end{array}$ & $\begin{array}{c}\text { Financial } \\
\text { liberalization } \\
(4) \\
\end{array}$ & $\begin{array}{c}\text { Terms of } \\
\text { trade } \\
(5) \\
\end{array}$ & $\begin{array}{c}\text { Government } \\
\text { spending/GDP } \\
(6) \\
\end{array}$ & $\begin{array}{c}\text { Growth spurt } \\
(7)\end{array}$ & $\begin{array}{l}\text { Horse } \\
\text { race } \\
(8) \\
\end{array}$ \\
\hline Log (St. dev. 5-year GDP growth) & $\begin{array}{l}0.075 \\
(0.224)\end{array}$ & $\begin{array}{l}0.005 \\
(0.089)\end{array}$ & $\begin{array}{l}0.312 * * * \\
(0.117)\end{array}$ & $\begin{array}{l}0.060 \\
(0.087)\end{array}$ & $\begin{array}{l}-0.326 \\
(0.238)\end{array}$ & $\begin{array}{l}-0.388 * * * \\
(0.142)\end{array}$ & $\begin{array}{l}-0.087 \\
(0.086)\end{array}$ & $\begin{array}{l}0.286 \\
(0.284)\end{array}$ \\
\hline Recession & $\begin{array}{l}-0.303 \\
(0.857)\end{array}$ & & & & & & & $\begin{array}{l}-1.351 \\
(0.964)\end{array}$ \\
\hline Banking crisis & & $\begin{array}{l}0.060 \\
(0.190)\end{array}$ & & & & & & $\begin{array}{l}0.027 \\
(0.179)\end{array}$ \\
\hline Private credit / GDP & & & $\begin{array}{l}-4.048 * * * \\
(0.949)\end{array}$ & & & & & $\begin{array}{l}-2.481 * * \\
(1.040)\end{array}$ \\
\hline Financial liberalization & & & & $\begin{array}{l}-1.927^{* * *} \\
(0.708)\end{array}$ & & & & $\begin{array}{l}-1.052 \\
(0.759)\end{array}$ \\
\hline St. dev. (Terms of trade) & & & & & $\begin{array}{l}22.533 * * \\
(11.387)\end{array}$ & & & -------- \\
\hline Government spending / GDP & & & & & & $\begin{array}{l}9.437 * * * \\
(2.821)\end{array}$ & & $\begin{array}{l}6.028 * * \\
(2.882)\end{array}$ \\
\hline Growth spurt & & & & & & & $\begin{array}{l}2.946 * * * \\
(0.828)\end{array}$ & $\begin{array}{l}2.212 * * * \\
(0.892)\end{array}$ \\
\hline Log (St. dev. 10-year GDP growth) $\times$ & 0.153 & & & & & & & -0.130 \\
\hline Recession & $(0.224)$ & & & & & & & $(0.249)$ \\
\hline Log (St. dev. 10-year GDP growth) $\times$ & & 0.038 & & & & & & 0.012 \\
\hline Banking crisis & & $(0.062)$ & & & & & & $(0.058)$ \\
\hline Log (St. dev. 10-year GDP growth) $\times$ & & & $-0.913 * * *$ & & & & & $-0.549 * *$ \\
\hline Private credit/GDP & & & $(0.261)$ & & & & & $(0.290)$ \\
\hline Log (St. dev. 10-year GDP growth) $\times$ & & & & $-0.427 * * *$ & & & & -0.219 \\
\hline Financial liberalization & & & & $(0.196)$ & & & & $(0.212)$ \\
\hline Log (St. dev. 10-year GDP growth) $\times$ & & & & & $6.616^{*}$ & & & -------- \\
\hline Log (Terms of trade) & & & & & $(3.517)$ & & & \\
\hline Log (St. dev. 10-year GDP growth) $\times$ & & & & & & $3.139 * * *$ & & $1.982 * *$ \\
\hline Government spending/ GDP & & & & & & $(0.943)$ & & $(0.990)$ \\
\hline Log (St. dev. 10-year GDP growth) $\times$ & & & & & & & $0.889 * * *$ & $0.908 * * *$ \\
\hline Growth spurt & & & & & & & $(0.305)$ & $(0.340)$ \\
\hline Country dummies & Yes & Yes & Yes & Yes & Yes & Yes & Yes & Yes \\
\hline Period dummies & Yes & Yes & Yes & Yes & Yes & Yes & Yes & Yes \\
\hline
\end{tabular}




\begin{tabular}{lllllll} 
Observations & 550 & 550 & 499 & 550 & 290 & 550 \\
Countries & 110 & 110 & 108 & 110 & 104 & 110 \\
R-squared & 0.33 & 0.24 & 0.30 & 0.26 & 0.42 & 0.26 \\
\hline Notes: The skewness and the standard deviation of GDP growth are calculated for all countries in the sample for ten-year non-overlapping periods over
\end{tabular}

Notes: The skewness and the standard deviation of GDP growth are calculated for all countries in the sample for ten-year non-overlapping periods over 1960-2009. Data on GDP growth from the 7.0 update of the Penn World Table are used. Recession is an indicator variable equal to 1 if the country experiences at least 1 year of negative GDP growth during each respective ten-year period. Banking crisis is an indicator variable equal to 1 if the country experiences a systemic banking crisis as defined by Laeven and Valencia (2010) during each respective ten-year period. Private credit / GDP is the average of the ratio of credit to the private sector to GDP during each respective ten-year period. Financial liberalization is an indicator variable equal to 1 if the country has liberalized its stock market according to the Bekaert, Harvey, and Lundblad (2005) classification at the beginning of each respective ten-year period. St. dev. (Terms of trade) is the standard deviation of the first (log) difference of the terms of trade over each respective ten-year period. Government spending / GDP is the ratio of government spending to GDP for each respective country in the beginning of each ten-year period. Growth spurt is an indicator variable equal to 1 if the country experiences an average growth rate higher than the sample average by two standard deviations or more during each respective ten-year period. The threshold corresponds to an average annual growth of 0.077 over ten years. All regressions include country and period fixed effects. Standard errors are provided in parentheses. *** indicates a p-value less than $0.01, * *$ indicates a p-value less than 0.05 , * indicates a p-value less than 0.10 . 
Table 6 - Growth Spurt Episodes

\begin{tabular}{|c|c|c|c|c|}
\hline Country & Period & $\begin{array}{l}\text { Average annual } \\
\text { GDP growth }\end{array}$ & $\begin{array}{l}\text { GDP skewness, } \\
1960-2009\end{array}$ & Event \\
\hline \multirow[t]{2}{*}{ Botswana } & 1970-1979 & 0.120 & 0.531 & $\begin{array}{l}\text { In 1966, newly independent Botswana embarks on a program of economic } \\
\text { liberalization under Prime Minister (and later President) Khama. }\end{array}$ \\
\hline & 1980-1989 & 0.079 & 0.531 & Diamonds are discovered. Diamonds now constitute $62 \%$ of Botswana’s exports. \\
\hline China & 2000-2009 & 0.092 & -1.304 & $\begin{array}{l}\text { The economy of China growth by more than } 11.5 \% \text { annually between } 2005 \text { and } 2007 \text {, } \\
\text { fuelled by strong foreign demand for its exports. }\end{array}$ \\
\hline \multirow{2}{*}{ Equatorial Guinea } & 1990-1999 & 0.269 & 2.676 & Discovery and subsequent exploration of large oil reserves. As a result, Equatorial \\
\hline & 2000-2009 & 0.177 & 2.676 & Guinea has emerged as the third-largest oil producer in Sub-Saharan Africa. \\
\hline Hong Kong & 1960-1969 & 0.080 & 0.505 & Hong Kong continues the policy of rapid industrialization embarked upon in the 1950s. \\
\hline Japan & 1960-1969 & 0.096 & 0.383 & Rapid industrialization, continuing a trend since the early 1950s. \\
\hline Malawi & 1960-1969 & 0.090 & 0.726 & Rapid economic growth based on the export of agricultural products. \\
\hline Mauritania & $1960-1964$ & 0.090 & 2.613 & Iron mines start operating in 1963. \\
\hline \multirow[t]{2}{*}{ Romania } & 1960-1969 & 0.079 & -0.636 & Rapid state-enforced industrialization which transforms the domestic economy, \\
\hline & 1970-1979 & 0.095 & -0.636 & fuelled to a large degree by foreign credit. \\
\hline Seychelles & 1970-1979 & 0.084 & 0.343 & $\begin{array}{l}\text { Rapid growth led by the tourist sector (which now employs around } 30 \% \text { of the labor } \\
\text { force) in the wake of independence. }\end{array}$ \\
\hline Singapore & 1970-1979 & 0.079 & -0.969 & $\begin{array}{l}\text { Following separation from Malaysia in 1965, the government adopts a pro-foreign } \\
\text { investment, export-oriented economic policy combined with investment in strategic } \\
\text { government-owned companies. }\end{array}$ \\
\hline Taiwan & 1970-1979 & 0.081 & -0.781 & $\begin{array}{l}\text { The economy of Taiwan, which had already become industrialized and technology- } \\
\text { oriented, benefits from strong global demand for its products. }\end{array}$ \\
\hline $\begin{array}{l}\text { Trinidad and } \\
\text { Tobago }\end{array}$ & 2000-2009 & 0.095 & 0.216 & $\begin{array}{l}\text { A global demand-driven boom in the production of oil, petrochemicals, and liquefied } \\
\text { natural gas. }\end{array}$ \\
\hline Zambia & 2000-2009 & 0.085 & 2.780 & $\begin{array}{l}\text { Substantial growth in copper exports due to rising world prices. At present, copper } \\
\text { and copper products constitute } 69 \% \text { of Zambia's exports. }\end{array}$ \\
\hline
\end{tabular}


Table 7 - The Skewness of GDP Growth and the Natural Logarithm of the Standard Deviation of GDP Growth: Robust Growth Spurt Episodes

\begin{tabular}{|c|c|c|c|}
\hline & $\begin{array}{c}\text { Excluding growth } \\
\text { spurts preceded by } \\
\text { declines } \\
(1)\end{array}$ & $\begin{array}{l}\text { Including "growth } \\
\text { miracles" } \\
\text { (2) }\end{array}$ & $\begin{array}{l}\text { Accounting for pre- } \\
\text { growth risk taking } \\
\text { (3) }\end{array}$ \\
\hline Log (St. dev. 5-year GDP growth) & $\begin{array}{l}-0.091 \\
(0.086)\end{array}$ & $\begin{array}{l}-0.076 \\
(0.088)\end{array}$ & $\begin{array}{l}0.002 \\
(0.101)\end{array}$ \\
\hline Growth spurt & $\begin{array}{l}2.525^{* * * *} \\
(1.064)\end{array}$ & $\begin{array}{l}1.933^{* * * *} \\
(0.707)\end{array}$ & $\begin{array}{l}2.605^{* * *} \\
(1.049)\end{array}$ \\
\hline Log (St. dev. 5-year GDP growth) $\times$ Growth spurt & $\begin{array}{l}0.766 * * \\
(0.378)\end{array}$ & $\begin{array}{l}0.543 * * \\
(0.244)\end{array}$ & $\begin{array}{l}0.776 * * \\
(0.383)\end{array}$ \\
\hline 1-period lagged 10-year GDP skewness & & & $\begin{array}{l}-0.206^{* * *} \\
(0.058)\end{array}$ \\
\hline Country dummies & Yes & Yes & Yes \\
\hline Period dummies & Yes & Yes & Yes \\
\hline Observations & 548 & 550 & 440 \\
\hline Countries & 110 & 110 & 110 \\
\hline R-squared & 0.26 & 0.26 & 0.35 \\
\hline \multicolumn{4}{|c|}{$\begin{array}{l}\text { Notes: The skewness and the standard deviation of GDP growth are calculated for all countries in the sample for ten- } \\
\text { year non-overlapping periods over } 1960-2009 \text {. Data on GDP growth from the } 7.0 \text { update of the Penn World Table } \\
\text { are used. Growth spurt is an indicator variable equal to } 1 \text { if the country experiences an average growth rate higher } \\
\text { than the sample average by two standard deviations or more during each respective ten-year period. The threshold } \\
\text { corresponds to an average annual growth of } 0.077 \text { over ten years. In column (1), we exclude growth spurts preceded } \\
\text { by a decline (i.e., negative growth on average during the preceding } 10 \text {-year period). In column (2), the definition of } \\
\text { "growth spurt" also includes episodes where a country experienced at least two consecutive ten-year periods with } \\
\text { annual growth higher than } 0.05 \text {. All regressions include country and period fixed effects. Standard errors are } \\
\text { provided in parentheses. *** indicates a p-value less than } 0.01 \text {, ** indicates a p-value less than } 0.05, * \text { indicates a p- } \\
\text { value less than } 0.10 \text {. }\end{array}$} \\
\hline
\end{tabular}


Table 8 - The Skewness of GDP Growth and the Natural Logarithm of the Standard Deviation of GDP Growth: Testing for the "Volatility Paradox"

\begin{tabular}{lcc}
\hline \hline & $\begin{array}{c}\text { Full sample } \\
(1)\end{array}$ & $\begin{array}{c}\text { Top 33\% private credit } \\
(2)\end{array}$ \\
\hline 1-period lagged log (St. dev. 10-year GDP growth) & 0.264 & $0.674^{*}$ \\
1-period lagged private credit / GDP & $(0.349)$ & $(0.435)$ \\
1-period lagged log (St. dev. 10-year GDP growth) & -0.048 & $-0.600^{* *}$ \\
& $(0.149)$ & $(0.312)$ \\
1-period lagged private credit / GDP & 0.554 & 2.337 \\
& $(1.268)$ & $(1.624)$ \\
Country variables & Yes & Yes \\
Country dummies & Yes & Yes \\
Period dummies & Yes & 134 \\
Observations & 391 & 36 \\
Countries & 108 & 0.48 \\
R-squared & 0.43 & \\
\hline Notes: The skewness of GDP growth, the standard deviation of GDP growth, and the ratio of private sector to GDP \\
are calculated for all countries in the sample for 5 ten-year periods over 1960-2009. Data on GDP growth from the \\
7.0 update of the Penn World Table are used. The regressions include the rest of the explanatory variables from \\
Table 4, as well as country and period fixed effects. Standard errors are provided in parentheses. ** indicates a p- \\
value less than 0.05, * indicates a p-value less than 0.10.
\end{tabular}




\section{Appendix Table 1 - Description of Variables}

\begin{tabular}{|c|c|}
\hline Variable & Description \\
\hline Standard deviation of GDP growth & $\begin{array}{l}\text { Standard deviation of the growth rate of GDP. Calculated over the 1960- } \\
2009 \text { in the cross-section regressions, or over non-overlapping } 10 \text {-year } \\
\text { periods in the panel regressions. The underlying data on GDP growth } \\
\text { (GRGDPCH) come from the World Penn Tables. }\end{array}$ \\
\hline Skewness of GDP growth & $\begin{array}{l}\text { The skewness of the growth rate of GDP. Calculated over the 1960-2009 } \\
\text { in the cross-section regressions, or over non-overlapping 10-year periods } \\
\text { in the panel regressions. The underlying data on GDP growth } \\
\text { (GRGDPCH) come from the World Penn Tables. }\end{array}$ \\
\hline Initial GDP per capita & $\begin{array}{l}\text { GDP per capita (RGDPCH) in 1960, from the Wold Penn Tables, in PPP } \\
\text { converted } 2005 \text { constant prices. }\end{array}$ \\
\hline GDP per capita & $\begin{array}{l}\text { Average GDP per capita (RGDPCH) for non-overlapping } 10 \text {-year } \\
\text { periods, from the Wold Penn Tables, in PPP converted } 2005 \text { constant } \\
\text { prices. }\end{array}$ \\
\hline Recession & $\begin{array}{l}\text { A dummy variable equal to } 1 \text { if the country experiences a negative } \\
\text { growth in at least one year during each non-overlapping } 10 \text {-year period. } \\
\text { The underlying data on GDP growth (GRGDPCH) come from the World } \\
\text { Penn Tables. }\end{array}$ \\
\hline Banking crisis & $\begin{array}{l}\text { A dummy equal to } 1 \text { if the country experiences a systemic banking crisis } \\
\text { during each non-overlapping 10-year period. The underlying data come } \\
\text { from Laeven and Valencia (2010). }\end{array}$ \\
\hline Private credit / GDP & $\begin{array}{l}\text { The value of total credits by financial intermediaries to the private sector } \\
\text { in each country, excluding credit by central banks. From Beck et al. } \\
\text { (2010). }\end{array}$ \\
\hline Financial liberalization & $\begin{array}{l}\text { A dummy equal to } 1 \text { if the country has liberalized its stock markets. } \\
\text { From Bekaert, Harvey, and Lundblad (2005). }\end{array}$ \\
\hline Terms of trade & $\begin{array}{l}\text { The percentage ratio of the export unit value indices to the import unit } \\
\text { value indices, measured relative to the base year (2000). From the World } \\
\text { Bank Development Indicators }\end{array}$ \\
\hline Government spending & $\begin{array}{l}\text { The share of government consumption of PPP converted GDP per capita } \\
\text { at current prices. The underlying data (KG) come from the World Penn } \\
\text { Tables. }\end{array}$ \\
\hline Growth spurt & $\begin{array}{l}\text { A dummy equal to } 1 \text { if over a non-overlapping } 10 \text {-year period the } \\
\text { country is experiencing a) average growth higher than } 0.077 \text { (which } \\
\text { corresponds to growth higher than the average growth for the sample by } \\
\text { two standard deviations), and b) at least two years of high growth (more } \\
\text { than twice the sample average). The underlying data on GDP growth } \\
\text { (GRGDPCH) come from the World Penn Tables. }\end{array}$ \\
\hline
\end{tabular}


Appendix Table 2 - Summary Statistics

\begin{tabular}{|c|c|c|c|c|c|c|c|c|c|c|}
\hline Country & $\begin{array}{c}\text { St. dev. of } \\
\text { GDP growth }\end{array}$ & $\begin{array}{l}\text { Skewness of } \\
\text { GDP growth }\end{array}$ & $\begin{array}{c}\text { Initial GDP } \\
\text { per capita }\end{array}$ & $\begin{array}{c}\text { GDP per } \\
\text { capita }\end{array}$ & Recession & Banking crisis & $\begin{array}{c}\text { Private credit } \\
\text { / GDP }\end{array}$ & $\begin{array}{c}\text { Financial } \\
\text { liberalization }\end{array}$ & $\begin{array}{c}\text { Government } \\
\text { spending } \\
\end{array}$ & $\begin{array}{c}\text { Growth } \\
\text { spurt }\end{array}$ \\
\hline Algeria & 0.082 & -1.533 & 4078.73 & 4566.10 & 1.0 & 0.2 & 0.312 & 0.0 & 0.11 & 0.0 \\
\hline Argentina & 0.047 & -0.360 & 6243.57 & 7737.32 & 1.0 & 0.6 & 0.182 & 0.2 & 0.09 & 0.0 \\
\hline Australia & 0.019 & -0.721 & 13116.90 & 22469.17 & 0.8 & 0.0 & 0.523 & 0.8 & 0.10 & 0.0 \\
\hline Austria & 0.025 & 0.514 & 10632.79 & 22055.97 & 0.6 & 0.2 & 0.752 & 1.0 & 0.10 & 0.0 \\
\hline Bangladesh & 0.039 & -1.227 & 802.07 & 821.62 & 0.8 & 0.2 & 0.169 & 0.2 & 0.02 & 0.0 \\
\hline Barbados & 0.053 & -0.252 & 7647.78 & 17615.75 & 1.0 & 0.0 & 0.494 & 0.8 & 0.16 & 0.0 \\
\hline Belgium & 0.023 & -0.616 & 10240.59 & 21131.76 & 0.8 & 0.2 & 0.427 & 1.0 & 0.11 & 0.0 \\
\hline Benin & 0.057 & 0.793 & 801.33 & 974.61 & 1.0 & 0.4 & 0.154 & 0.4 & 0.11 & 0.0 \\
\hline Bolivia & 0.036 & -2.291 & 2713.58 & 2969.17 & 0.8 & 0.4 & 0.252 & 0.4 & 0.07 & 0.0 \\
\hline Botswana & 0.103 & 0.531 & 578.04 & 3814.91 & 1.0 & 0.0 & 0.141 & 0.6 & 0.09 & 0.4 \\
\hline Brazil & 0.042 & 0.053 & 2581.05 & 5435.64 & 0.6 & 0.2 & 0.424 & 0.2 & 0.12 & 0.0 \\
\hline Burkina Faso & 0.058 & 1.364 & 589.88 & 654.81 & 1.0 & 0.2 & 0.107 & 0.2 & 0.14 & 0.0 \\
\hline Burundi & 0.076 & 1.215 & 258.73 & 364.25 & 1.0 & 0.2 & 0.104 & 0.2 & 0.16 & 0.0 \\
\hline Cameroon & 0.056 & 0.128 & 1241.29 & 1621.81 & 1.0 & 0.4 & 0.161 & 0.2 & 0.06 & 0.0 \\
\hline Canada & 0.021 & -0.911 & 12987.91 & 23155.21 & 0.8 & 0.0 & 0.816 & 1.0 & 0.10 & 0.0 \\
\hline Cape Verde & 0.070 & -0.471 & 1052.97 & 1523.91 & 0.8 & 0.2 & 0.289 & 0.2 & 0.12 & 0.0 \\
\hline Central African & 0.043 & -0.234 & 1073.57 & 875.48 & 1.0 & 0.4 & 0.103 & 0.0 & 0.21 & 0.0 \\
\hline Chad & 0.088 & 1.132 & 818.61 & 755.04 & 1.0 & 0.4 & 0.076 & 0.0 & 0.53 & 0.0 \\
\hline Chile & 0.055 & -1.715 & 3780.41 & 5703.89 & 1.0 & 0.4 & 0.455 & 0.6 & 0.07 & 0.0 \\
\hline China & 0.060 & -1.304 & 846.79 & 1593.25 & 0.6 & 0.2 & 0.815 & 0.0 & 0.16 & 0.2 \\
\hline Colombia & 0.035 & 1.427 & 2478.32 & 4038.85 & 1.0 & 0.6 & 0.264 & 0.4 & 0.04 & 0.0 \\
\hline Comoros & 0.048 & 0.744 & 757.21 & 1134.94 & 1.0 & 0.0 & 0.123 & 0.0 & 0.34 & 0.0 \\
\hline Congo, Dem. Rep. & 0.131 & 1.486 & 1092.26 & 751.35 & 1.0 & 0.4 & 0.022 & 0.0 & 0.07 & 0.0 \\
\hline Congo, Rep. & 0.077 & 0.332 & 791.10 & 1701.64 & 1.0 & 0.0 & 0.144 & 0.0 & 0.11 & 0.0 \\
\hline Costa Rica & 0.033 & -1.326 & 5023.87 & 7269.44 & 0.8 & 0.4 & 0.246 & 0.4 & 0.18 & 0.0 \\
\hline Cote d'Ivoire & 0.050 & 0.246 & 977.11 & 1415.79 & 1.0 & 0.0 & 0.260 & 0.0 & 0.07 & 0.0 \\
\hline Cyprus & 0.081 & -0.283 & 3335.81 & 10176.50 & 0.8 & 0.0 & 1.229 & 1.0 & 0.09 & 0.0 \\
\hline Denmark & 0.026 & -0.196 & 12122.61 & 22133.15 & 1.0 & 0.2 & 0.698 & 1.0 & 0.10 & 0.0 \\
\hline Dominican Rep. & 0.050 & -0.349 & 2354.83 & 4312.09 & 0.8 & 0.2 & 0.223 & 0.2 & 0.08 & 0.0 \\
\hline Ecuador & 0.045 & -0.006 & 2806.84 & 4218.32 & 0.8 & 0.6 & 0.219 & 0.2 & 0.07 & 0.0 \\
\hline Egypt & 0.044 & 0.801 & 1036.31 & 2123.88 & 0.6 & 0.2 & 0.280 & 0.2 & 0.10 & 0.0 \\
\hline
\end{tabular}




\begin{tabular}{|c|c|c|c|c|c|c|c|c|c|c|}
\hline El Salvador & 0.034 & -1.085 & 3397.20 & 4282.45 & 1.0 & 0.0 & 0.304 & 0.4 & 0.12 & 0.0 \\
\hline Equatorial Guinea & 0.242 & 2.676 & 567.66 & 1683.62 & 1.0 & 0.2 & 0.116 & 0.0 & 0.17 & 0.4 \\
\hline Ethiopia & 0.069 & 0.575 & 388.04 & 435.09 & 0.8 & 0.0 & 0.151 & 0.2 & 0.09 & 0.0 \\
\hline Fiji & 0.059 & 1.003 & 1977.48 & 3189.56 & 1.0 & 0.0 & 0.250 & 0.0 & 0.10 & 0.0 \\
\hline Finland & 0.036 & -1.091 & 9080.45 & 18941.17 & 0.6 & 0.2 & 0.571 & 1.0 & 0.10 & 0.0 \\
\hline France & 0.020 & -0.463 & 10101.31 & 20317.96 & 0.6 & 0.2 & 0.804 & 1.0 & 0.10 & 0.0 \\
\hline Gabon & 0.091 & 0.585 & 4518.43 & 9703.61 & 1.0 & 0.0 & 0.143 & 0.0 & 0.04 & 0.0 \\
\hline Gambia & 0.072 & 1.780 & 958.06 & 866.14 & 1.0 & 0.0 & 0.157 & 0.4 & 0.22 & 0.0 \\
\hline Ghana & 0.116 & 0.308 & 603.04 & 815.98 & 0.8 & 0.2 & 0.073 & 0.4 & 0.13 & 0.0 \\
\hline Greece & 0.038 & -0.130 & 6181.45 & 15066.81 & 0.8 & 0.2 & 0.365 & 1.0 & 0.09 & 0.0 \\
\hline Guatemala & 0.026 & -0.008 & 2986.78 & 4595.91 & 0.6 & 0.0 & 0.168 & 0.4 & 0.11 & 0.0 \\
\hline Guinea & 0.042 & -0.553 & 977.34 & 854.86 & 1.0 & 0.4 & 0.040 & 0.4 & 0.09 & 0.0 \\
\hline Guinea-Bissau & 0.163 & 2.674 & 344.06 & 380.41 & 1.0 & 0.2 & 0.107 & 0.4 & 0.14 & 0.0 \\
\hline Haiti & 0.044 & 0.120 & 1887.87 & 1849.94 & 1.0 & 0.2 & 0.135 & 0.0 & 0.18 & 0.0 \\
\hline Honduras & 0.036 & -0.233 & 2235.43 & 2792.16 & 1.0 & 0.0 & 0.296 & 0.2 & 0.18 & 0.0 \\
\hline Hong Kong & 0.053 & 0.505 & 3339.60 & 15078.00 & 0.8 & 0.0 & 1.492 & 1.0 & 0.03 & 0.2 \\
\hline Iceland & 0.052 & -0.013 & 10500.92 & 21987.96 & 1.0 & 0.2 & 0.667 & 1.0 & 0.08 & 0.0 \\
\hline India & 0.035 & 0.274 & 711.38 & 1176.56 & 0.6 & 0.2 & 0.223 & 0.2 & 0.11 & 0.0 \\
\hline Indonesia & 0.046 & -1.755 & 692.51 & 1682.77 & 0.6 & 0.4 & 0.308 & 0.8 & 0.09 & 0.0 \\
\hline Iran & 0.089 & -1.229 & 4403.94 & 6574.42 & 1.0 & 0.0 & 0.222 & 0.0 & 0.12 & 0.0 \\
\hline Ireland & 0.038 & -0.895 & 6970.00 & 15869.14 & 0.6 & 0.2 & 0.659 & 0.8 & 0.07 & 0.0 \\
\hline Israel & 0.039 & 0.726 & 7093.35 & 15178.18 & 1.0 & 0.2 & 0.559 & 0.4 & 0.17 & 0.0 \\
\hline Italy & 0.028 & -0.437 & 8858.11 & 19360.06 & 0.6 & 0.0 & 0.658 & 1.0 & 0.10 & 0.0 \\
\hline Jamaica & 0.040 & 0.636 & 5609.14 & 7079.85 & 1.0 & 0.2 & 0.237 & 0.4 & 0.14 & 0.0 \\
\hline Japan & 0.041 & 0.383 & 5850.43 & 19314.34 & 0.6 & 0.4 & 1.496 & 0.8 & 0.10 & 0.2 \\
\hline Jordan & 0.080 & -0.120 & 2681.55 & 3563.70 & 1.0 & 0.4 & 0.488 & 0.8 & 0.11 & 0.0 \\
\hline Kenya & 0.036 & -0.327 & 1020.12 & 1103.26 & 1.0 & 0.4 & 0.245 & 0.2 & 0.05 & 0.0 \\
\hline Korea & 0.045 & -1.257 & 1782.05 & 8102.27 & 0.8 & 0.2 & 0.492 & 0.8 & 0.10 & 0.0 \\
\hline Lesotho & 0.073 & 0.335 & 400.74 & 748.40 & 1.0 & 0.0 & 0.133 & 0.0 & 0.04 & 0.0 \\
\hline Luxembourg & 0.039 & -0.371 & 17353.40 & 34698.53 & 1.0 & 0.2 & 0.987 & 1.0 & 0.07 & 0.0 \\
\hline Madagascar & 0.053 & 0.356 & 841.97 & 866.01 & 1.0 & 0.2 & 0.139 & 0.2 & 0.08 & 0.0 \\
\hline Malawi & 0.115 & 0.726 & 329.07 & 603.40 & 1.0 & 0.0 & 0.039 & 0.0 & 0.10 & 0.2 \\
\hline Malaysia & 0.048 & -0.269 & 1470.16 & 4713.03 & 0.8 & 0.2 & 0.707 & 0.8 & 0.05 & 0.0 \\
\hline Mali & 0.063 & -0.329 & 541.37 & 603.10 & 1.0 & 0.4 & 0.157 & 0.4 & 0.11 & 0.0 \\
\hline
\end{tabular}




\begin{tabular}{|c|c|c|c|c|c|c|c|c|c|c|}
\hline Mauritania & 0.092 & 2.613 & 586.95 & 1152.73 & 1.0 & 0.2 & 0.223 & 0.2 & 0.22 & 0.2 \\
\hline Mauritius & 0.062 & -0.603 & 2208.24 & 3939.48 & 0.8 & 0.0 & 0.419 & 0.8 & 0.08 & 0.0 \\
\hline Mexico & 0.042 & -0.698 & 4588.56 & 7938.04 & 0.8 & 0.4 & 0.223 & 0.4 & 0.03 & 0.0 \\
\hline Morocco & 0.063 & 0.496 & 736.76 & 1844.45 & 1.0 & 0.2 & 0.249 & 0.4 & 0.04 & 0.0 \\
\hline Mozambique & 0.050 & -0.540 & 357.70 & 416.59 & 0.8 & 0.4 & 0.153 & 0.2 & 0.07 & 0.0 \\
\hline Namibia & 0.055 & 0.541 & 2481.49 & 3366.28 & 1.0 & 0.0 & 0.431 & 0.0 & 0.08 & 0.0 \\
\hline Nepal & 0.030 & -0.714 & 632.24 & 791.95 & 0.8 & 0.2 & 0.142 & 0.2 & 0.08 & 0.0 \\
\hline Netherlands & 0.021 & -0.182 & 13017.26 & 23183.57 & 0.8 & 0.2 & 0.899 & 1.0 & 0.16 & 0.0 \\
\hline New Zealand & 0.033 & 0.682 & 13802.20 & 18149.21 & 1.0 & 0.0 & 0.557 & 0.4 & 0.10 & 0.0 \\
\hline Nicaragua & 0.094 & -1.011 & 2546.28 & 2707.07 & 1.0 & 0.4 & 0.251 & 0.2 & 0.21 & 0.0 \\
\hline Niger & 0.072 & -0.366 & 746.19 & 640.93 & 1.0 & 0.2 & 0.092 & 0.2 & 0.15 & 0.0 \\
\hline Nigeria & 0.091 & 0.369 & 1527.86 & 1336.80 & 1.0 & 0.2 & 0.117 & 0.0 & 0.01 & 0.0 \\
\hline Norway & 0.019 & -0.343 & 12283.61 & 26597.99 & 0.4 & 0.0 & 0.487 & 1.0 & 0.08 & 0.0 \\
\hline Pakistan & 0.035 & -0.628 & 727.62 & 1423.19 & 0.8 & 0.0 & 0.241 & 0.0 & 0.10 & 0.0 \\
\hline Panama & 0.051 & 0.623 & 2170.94 & 4695.67 & 1.0 & 0.2 & 0.602 & 0.2 & 0.18 & 0.0 \\
\hline Papua New Guinea & 0.098 & 3.981 & 886.96 & 1647.81 & 0.8 & 0.0 & 0.186 & 0.0 & 0.22 & 0.0 \\
\hline Paraguay & 0.040 & 0.735 & 1847.32 & 2970.56 & 0.8 & 0.2 & 0.196 & 0.4 & 0.05 & 0.0 \\
\hline Peru & 0.058 & -1.049 & 3758.60 & 4702.92 & 1.0 & 0.2 & 0.171 & 0.2 & 0.05 & 0.0 \\
\hline Philippines & 0.041 & -0.240 & 1314.36 & 1905.64 & 1.0 & 0.6 & 0.272 & 0.4 & 0.06 & 0.0 \\
\hline Portugal & 0.043 & -0.770 & 4002.81 & 11306.91 & 0.8 & 0.2 & 0.778 & 1.0 & 0.05 & 0.0 \\
\hline Puerto Rico & 0.041 & -0.129 & 5716.37 & 14524.60 & 0.8 & 0.0 & & 0.0 & 0.09 & 0.0 \\
\hline Romania & 0.061 & -0.636 & 1511.20 & 5042.87 & 0.6 & 0.2 & 0.143 & 0.2 & 0.08 & 0.4 \\
\hline Rwanda & 0.139 & 1.301 & 860.19 & 774.08 & 1.0 & 0.0 & 0.061 & 0.0 & 0.30 & 0.0 \\
\hline Senegal & 0.048 & 0.366 & 1421.40 & 1255.83 & 1.0 & 0.4 & 0.218 & 0.0 & 0.08 & 0.0 \\
\hline Seychelles & 0.104 & 0.343 & 3677.19 & 9831.44 & 0.8 & 0.0 & 0.195 & 0.0 & 0.32 & 0.2 \\
\hline Singapore & 0.047 & -0.969 & 4299.92 & 17348.45 & 0.8 & 0.0 & 0.743 & 0.8 & 0.09 & 0.2 \\
\hline South Africa & 0.030 & -0.512 & 3849.71 & 5308.02 & 0.8 & 0.0 & 0.882 & 0.2 & 0.05 & 0.0 \\
\hline Spain & 0.033 & 0.516 & 6294.55 & 15877.27 & 0.8 & 0.6 & 0.822 & 1.0 & 0.07 & 0.0 \\
\hline Sri Lanka & 0.024 & -0.369 & 765.12 & 1617.20 & 0.6 & 0.4 & 0.189 & 0.2 & 0.09 & 0.0 \\
\hline Sweden & 0.021 & -1.159 & 13322.57 & 22422.45 & 0.8 & 0.4 & 0.849 & 1.0 & 0.11 & 0.0 \\
\hline Switzerland & 0.024 & -1.062 & 18955.18 & 29213.42 & 0.8 & 0.2 & 1.289 & 1.0 & 0.05 & 0.0 \\
\hline Syria & 0.092 & 0.567 & 1600.01 & 2517.40 & 1.0 & 0.0 & 0.105 & 0.0 & 0.09 & 0.0 \\
\hline Taiwan & 0.036 & -0.781 & 1826.40 & 9916.95 & 0.2 & 0.0 & & 0.0 & 0.19 & 0.2 \\
\hline Tanzania & 0.045 & 0.760 & 481.38 & 632.31 & 0.8 & 0.2 & 0.087 & 0.2 & 0.06 & 0.0 \\
\hline
\end{tabular}




\begin{tabular}{|c|c|c|c|c|c|c|c|c|c|c|}
\hline Thailand & 0.039 & -1.283 & 961.44 & 3039.51 & 0.8 & 0.6 & 0.655 & 1.0 & 0.07 & 0.0 \\
\hline Turkey & 0.040 & -0.522 & 3243.48 & 5672.28 & 1.0 & 0.4 & 0.187 & 0.4 & 0.05 & 0.0 \\
\hline UK & 0.020 & -1.176 & 12841.08 & 20489.76 & 0.8 & 0.0 & 0.770 & 1.0 & 0.10 & 0.0 \\
\hline Uganda & 0.051 & 0.018 & 655.38 & 677.58 & 0.8 & 0.2 & 0.062 & 0.4 & 0.15 & 0.0 \\
\hline Uruguay & 0.055 & -0.609 & 4753.07 & 6161.00 & 1.0 & 0.4 & 0.318 & 0.4 & 0.06 & 0.0 \\
\hline Venezuela & 0.060 & -0.148 & 6662.75 & 8284.50 & 1.0 & 0.2 & 0.280 & 0.2 & 0.05 & 0.0 \\
\hline
\end{tabular}

